\title{
Mechanical characterization and properties of laser-based powder bed-fused lattice structures: a review
}

\author{
Leonardo Riva $^{1} \cdot$ Paola Serena Ginestra $^{1} \cdot$ Elisabetta Ceretti ${ }^{1}$ \\ Received: 8 October 2020 / Accepted: 11 January 2021 / Published online: 28 January 2021 \\ (C) The Author(s) 2021
}

\begin{abstract}
The increasing demand for a wider access to additive manufacturing technologies is driving the production of metal lattice structure with powder bed fusion techniques, especially laser-based powder bed fusion. Lattice structures are porous structures formed by a controlled repetition in space of a designed base unit cell. The tailored porosity, the low weight, and the tunable mechanical properties make the lattice structures suitable for applications in fields like aerospace, automotive, and biomedicine. Due to their wide-spectrum applications, the mechanical characterization of lattice structures is mostly carried out under compression tests, but recently, tensile, bending, and fatigue tests have been carried out demonstrating the increasing interest in these structures developed by academy and industry. Although their physical and mechanical properties have been extensively studied in recent years, there still are no specific standards for their characterization. In the absence of definite standards, this work aims to collect the parameters used by recent researches for the mechanical characterization of metal lattice structures. By doing so, it provides a comparison guide within tests already carried out, allowing the choice of optimal parameters to researchers before testing lattice samples. For every mechanical test, a detailed review of the process design, test parameters, and output is given, suggesting that a specific standard would enhance the collaboration between all the stakeholders and enable an acceleration of the translation process.
\end{abstract}

Keywords Additive manufacturing $\cdot$ Laser-based powder bed fusion $\cdot$ Compression test $\cdot$ Fatigue test $\cdot$ Bending test $\cdot$ Tensile test

\section{Introduction}

Additive manufacturing (AM), commonly known as 3D printing, has faced an extraordinary growth during the last years [1-3]. AM is defined by ASTM F2792 as "the process of joining materials to make objects from 3D model data, usually layer upon layer, as opposed to subtractive manufacturing methodologies" [4]. Briefly, a CAD model of the parts is divided in cross-sectional layers by a slicer software and uploaded into a printer that proceeds to build the object adding the material only where it is needed following the cross-section sequence [5]. AM was originally used for rapid prototyping purposes, but in the last few years, the quality and performances of the produced samples made it spread globally.

Leonardo Riva

1.riva006@unibs.it

1 Department of Industrial and Mechanical Engineering, University of Brescia, Via Branze 38, 25125 Brescia, Italy
This expansion is intended to continue in the next years; in fact, if the value of the AM market in 2016 was around 7 billion dollars, it is estimated to reach about 27 billion in 2022 [6]. Polymers are the most used material in AM, but in the last few years, metals have had the biggest growth rate. Among the technologies able to 3D print metals, laser-based powder bed fusion (PBFLB) is one of the most used. PBF-LB is a powder bed fusion system in which a laser beam is used to locally melt metallic powder. More specifically, a PBF-LB system consists in a roller, two platforms, and a laser [5]. The roller pushes a thin layer of metallic powder on the building platform; then, the laser melts the powder following a filling strategy of the cross section of the designed object [7]. Once the layer has been completely melted and solidified, the building platform moves down, the feeding platform rises, and the roller spreads another layer of powder (Fig. 1). The laser melts the second layer of powder that will adhere to the lower layer. Once the process is completed, the unmelted powder is typically collected with a vacuum cleaner to be reused. 


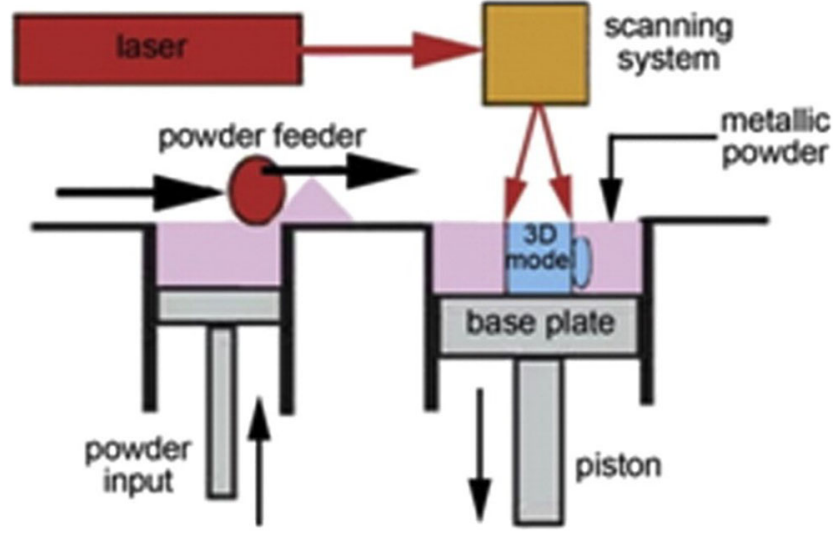

Fig. 1 Scheme of the laser-based powder bed fusion process [7]

PBF-LB allows the fabrication of almost fully dense metallic parts with the advantage of a high degree of precision and freedom of design $[8,9]$. In fact, it is possible to produce porous structures not obtainable with the traditional technologies [10]. These structures, called lattice, are composed of struts and nodes, where nodes are the meeting points of the struts' end. Lattices can be either stochastic or made by the repetition in different directions of a unit cell with a defined geometry [11]. Stochastic lattice structures have no fully predictable mechanical properties due to the random distribution and orientation of their struts and nodes, limiting their actual use. Unit cell lattice structures, instead, are the most studied due to their repeatable mechanical properties that can match the properties of bulk parts but with significant lower weight. Furthermore, they have demonstrated good energy absorption, as well as good thermal and acoustic insulation [12]. Lattice structures can be classified based on their deformation behavior, typically divided into two different deformation mechanisms: bendingdominated and stretch-dominated. Bending-dominated structures have lower mechanical strength and higher energy absorption properties while stretch-dominated structures have opposite characteristics [13]. Moreover, it is possible to predict the deformation behavior of the structure based on the geometry of the cell. Metal lattice structures have several possible applications, but the aerospace, automotive, and biomechanical fields are the main ones for lattice design and evaluation. The aerospace and automotive research is always looking for light-weight components with optimal mechanical properties to reduce fuel consumption and carbon emissions while maintaining the structural integrity and safety of the part [14]. Mines et al. [15] and Chantarapanich et al. [16] studied the mechanical properties of sandwich lattice panels as impact absorbers and load carrier. Bici et al. [17] investigated a novel wing leading edge that serves both as an impact absorber and as an anti-ice system. Miller et al. [18] patented a new system to protect a flight recorder. Büşra et al. [19], after topology optimizing a suspension arm, infilled it with lattice obtaining both strength improvement and weight reduction. On the other hand, in the biomedical field, the lattice structures are of particular interest for the production of bone scaffolds [20, 21]. Dr. Joseph became the first surgeon to use a lattice spinal implant during a surgical operation [22]. Many other researchers investigated the feasibility and mechanical properties of porous femoral, hip, and knee implants. Limmahakhun et al. [23] studied a graded femoral stem that controls the micromotions in an acceptable range for bone ingrowth with a flexural stiffness similar to the human bone. Hazlehurst et al. [24] developed a femoral stem $48 \%$ lighter and $60 \%$ more flexible than a traditional one. España et al. [25] built an implant with a Young modulus matching the cortical bone, reducing the stress shielding effect, and increasing the in vivo life. Moreover, Wang et al. [26] designed a hip prosthesis able to increase the stability of the bone-implant interfaces. Arabnejad et al. [27] developed a systematic approach to design hip implants with a considerable decrease of resorption secondary to stress shielding. Murr et al. [28] demonstrated a biocompatible, customized knee implant with comparable bone stiffness to the natural tissue. Furthermore, Wathule et al. [29] observed no cytotoxicity and good bone ingrowth on a lattice tantalum implant in an in vivo experiment on a rat femur.

For both the application fields mentioned above, the most studied material is the Ti-6Al-4V alloy due to its high mechanical properties and excellent biocompatibility; however, many other materials such as 316L stainless steel, $\mathrm{CoCr}$, and Al10Si-Mg have been studied.

Lattice structures have been deeply tested to characterize and validate their mechanical performances. Considering the overarching context of application, the compression test is the most used to characterize these structures, but in the last few years, tensile, fatigue, and bending tests have been carried out to broaden the knowledge of lattice mechanical response. The compression test is usually carried out following the ISO 13314 (related to compression tests for porous and cellular metals) that, although it is not specific for additively manufactured samples [30], provides good indications on which parameters to use during the test. For other characterization tests, there is not a standard for porous or cellular samples. In the absence of a specific international standard regarding the mechanical characterization of these structures, this review aims to point out which methodologies, instrumentations, and parameters are the most used by the researchers around the world to provide a possible useful guideline for further developments in 
design, evaluation, and applications of PBF-LB metal lattices. The review is intended to report the focal points of the PBF-LB process involving the design, material, and process parameters of the PBF-LB technology leading to the mechanical test parameters and outputs collected by several studies with different purposes and application objectives. Although many $3 \mathrm{D}$ technologies enable the production of metal lattice structures, the authors decided to focus on PBF-LB due to a several number of papers that report mechanical test data on PBF-LB lattice samples.

\section{Production process}

In this section, the fundamental aspects for the production of lattice structures will be illustrated, in particular, cell geometries, materials used, and printing parameters applied for the PBF-LB process.

\subsection{Cell geometry}

Cellular structures are available in nature to optimize energy consumption, such as honeycombs, bones, and wood. These structures, despite their light weight and high porosity, have a great load capacity and high functionality [31]. Many manufacturing techniques as investment casting, deformation forming, and metal wire approaches were used to produce these structures, but the processes were complex and with several drawbacks [32]. Only the recent development of 3D printing made the production of these structures, called lattice, really possible. Lattice structures consist of a base unit cell with a defined geometry repeated periodically in space [33]. Lattices can be categorized in different ways, 2D or 3D, random or periodic, open or closed [31], homogeneous or heterogeneous [34], but the most particular ones are strut-based or triply periodic minimal surfaces (TPMS). Within the strutbased lattice, the unit cell is composed of a group of crossbars (s) interconnected with each other in points called nodes (n). The most significant lattice structures are shown in Fig. 2 where the most used strut-based lattice structures are the body-centered cubic (BCC), the face-centered cubic (FCC), and the diamond lattices.

The number of struts (s) and nodes (n) of the unit cell is crucial to predict its deformation mechanism. In fact, they can influence the degree of connectivity and freedom of the unit cell that can be quantified with the Maxwell number (M) (Eq. 1):

$M=s-3 n+6$

where $M$ is the Maxwell number, $s$ is the number of struts, and $n$ is the number of nodes inside the unit cell. If $M<0$, the structure is under-stiff, the struts are unable to equilibrate the external forces, moments are transferred to the nodes, and the deformation behavior is bending-dominated. If $M \geq 0$, the structure is over/ just stiff, the moments are not transferred to the nodes, and the deformation behavior is stretch-dominated [36]. Stretching-

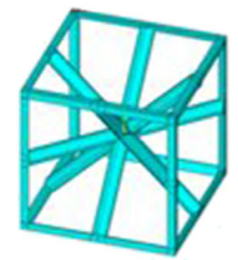

ACC

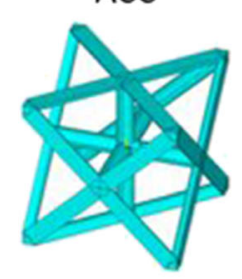

CFCC

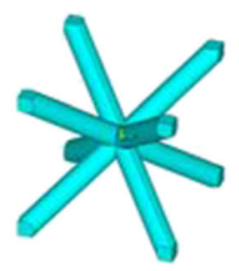

$\mathrm{BCC}$

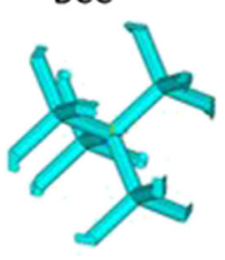

Diamond

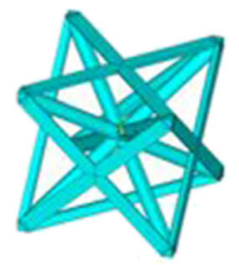

BFCC

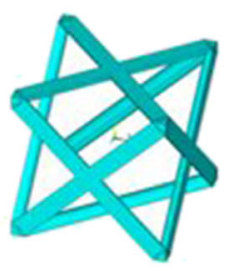

FCC

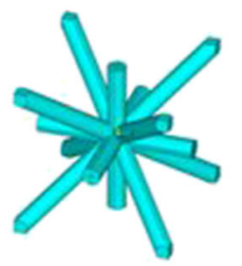

CBCC

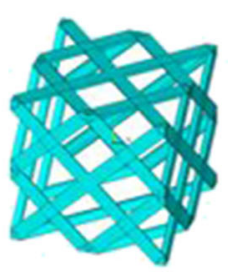

FCC2+

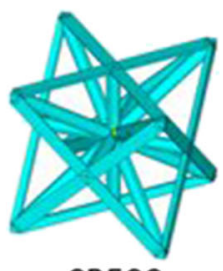

CBFCC

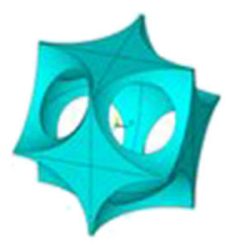

$\mathrm{iBCC}$

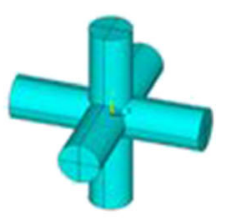

CC

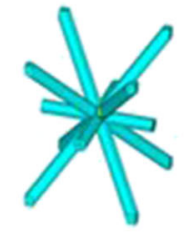

Octahedral

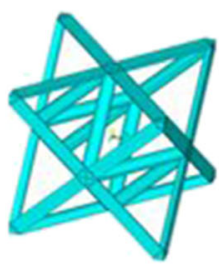

Octet

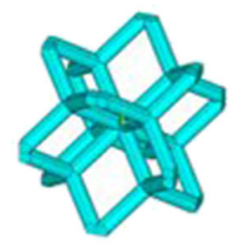

Rhombic dodecahedron

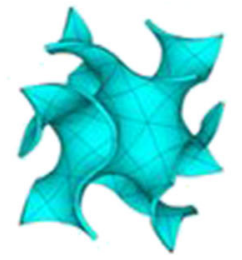

Shone Gyroid

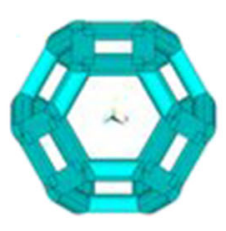

Truncated cuboctahedron cuboctahedron $2+$

Fig. 2 Examples of lattice structure unit cells [35] 
dominated structures are characterized by higher modulus and yield strength [37]. The higher the number of the struts and nodes, the higher the Maxwell number and the higher will be the mechanical strength and cell stiffness. Although the Maxwell number is a good method to predict the deformation behavior of the structure, it is not always a reliable coefficient since the strut configuration and alignment cannot improve the cell stiffness but increase the Maxwell number [36]. The unit cells of strut-based lattice structures cannot exceed $5 \mathrm{~mm}$ size due to manufacturability problems of overhanging struts [38]; however, the majority of the application requires smaller sizes.

As cited above, the other type of lattice structures is the triply periodic minimal surfaces, porous structures with zero mean curvature of the surface [39]. TPMS are generated by algorithms [31] and can be represented by mathematical equations. The main TPMS structures are the gyroid and the diamond represented by these equations (Eqs. 2 and 3) [39]:

Gyroid : $F(x, y, z)=\cos x * \sin y+\cos y * \sin z$

$$
+\cos z * \sin x+a
$$

Diamond : $F(x, y, z)=\sin x * \sin y * \sin z$

$$
\begin{aligned}
& +\sin x * \cos y * \cos z \\
& +\cos x * \sin y * \cos z \\
& +\cos x * \cos y * \sin z+a
\end{aligned}
$$

Anyhow, the most used TPMS structure is the gyroid (Fig. 3), without straight lines [41] but a spherical core and smooth struts, being self-supporting [38]. Contrary to the strut-based structures, TPMS structures have an inferior limit

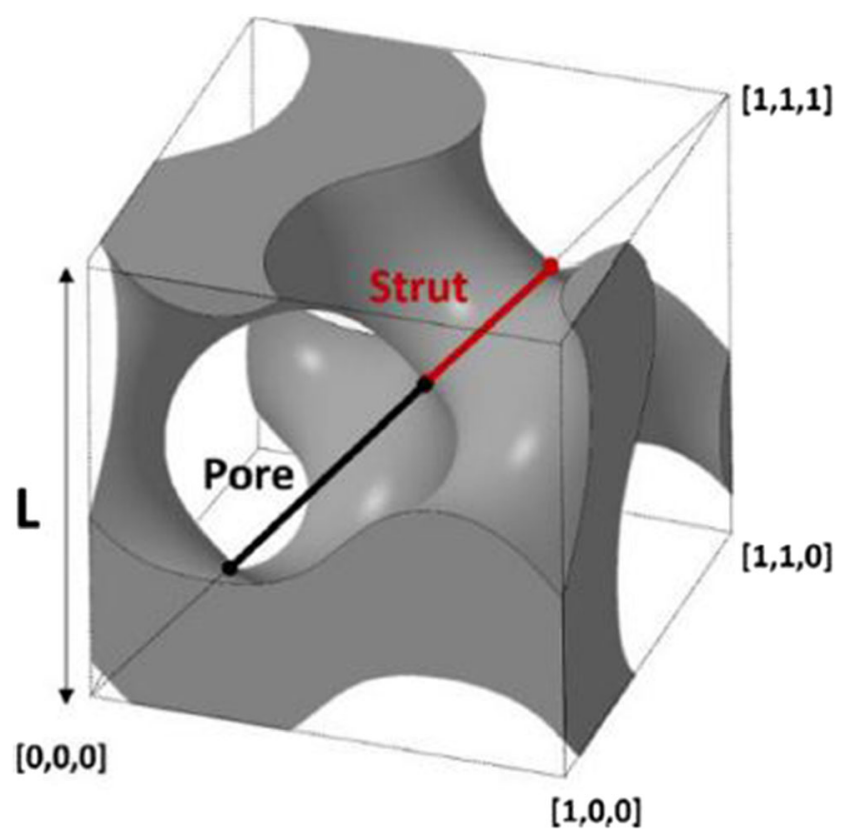

Fig. 3 Geometry and characteristics of the gyroid unit cell [40] on the unit cell size to allow the powder removal from the voids [38].

Regarding the general behavior of lattice structures, the deformation process usually is composed of three regions: elastic, yielding, and post-yielding where the stress reaches a maximum before dropping to a plateau related to the densification of the material [42]. The mechanical behavior is influenced by many factors including the printing process and the microstructure [42], but the material, topology, and relative density of the sample are the main aspects that control the structural properties [43]. Generally, if the relative density decreases, the stiffness and the strength decrease as well [44]. In particular, this relationship can be linear in the case of a stretching-dominated structure or in the form of a power law for a bending-dominated structure [45]. Typically, the relative density increases with the decrease of the unit cell size while the stiffness and strength decrease when the unit cell size increases [38]. For these reasons, the excessive reduction of the strut size can have an unexpected effect on the mechanical properties.

The design of a lattice structure is a two-step process: design of the unit cell and design of the pattern. There are three ways to design a unit cell: a primitive-based method, based on a Boolean operation of geometric primitives; an implicit surface-based method, based on equations that describe the surface of the unit cell in space; and topology optimization, based on algorithms that optimize the distribution of the material.

On the other hand, there are three methods for the pattern design: direct patterning, where the unit cell is repeated along the three dimensions (the most common technique); conformal patterning, where the unit cells are positioned in order to match a specific shape; or a topological optimization [32].

Lattice structures can be designed with conventional CAD systems with limits related to the cell repetition in large scale to obtain the structure. Alternatives are MATLAB ${ }^{\circledR}$ [11] or specialized tools. However, the printer-supporting software is typically equipped with an integrated library of the unit cell geometries, for example, the 3DXpert modules of the 3D systems ${ }^{\circledR}$ printers.

\subsection{Materials}

The most common materials used for the fabrication of lattice structures are Ti-6Al-4V, 316L stainless steel, CoCr, Al-Si alloys, and Ni alloys.

Ti-6Al-4V is the most used type of titanium around the world and holds alone almost half of the global titanium market [46]. It is an excellent material to be processed by PBF$\mathrm{LB}$, because in a liquid state, it is very reactive to elements like oxygen and nitrogen and the controlled atmosphere inside the printers limits this reaction [47]. However, the fast heating and cooling rates can generate thermal expansions and residual 
stresses in the fabricated titanium parts. To obtain a more stable melting [48] and a lower porosity that can reduce the anisotropy [49], a correct set of parameters should be chosen. Ti-6Al-4V has high strength, corrosion resistance, and biocompatibility combined with low density and thermal conductivity making it suitable for application in fields like aerospace and biomedicine; however, it is used also in automobile, energy, marine, and chemical industries [46, 50]. Concept Laser developed a topology-optimized titanium bracket connector with a weight reduction of more than $30 \%$ that has been installed on the Airbus A350 XWB [51]. Bugatti, in collaboration with Fraunhofer IAPT and Bionic Production AG, built the volumetrically largest functional component, consisting in a brake caliper meeting the requirements for a sport car production [52].

The 316L stainless steel is one of the most used materials due to its high welding performance, good durability, and anticorrosion properties [53]. It also has good PBF-LB processability [54]; nevertheless, it still presents some processing challenges. For example, the energy density must be between a certain range in order to avoid pore formation and vaporization of alloying elements that affect the mechanical properties [55]. $316 \mathrm{~L}$ is an austenitic steel with an elevated resistance to creep and oxidation up to $900{ }^{\circ} \mathrm{C}$ [56]. 316L is also biocompatible, which is used to produce plates, screw, and nails and also temporary low-cost cemented implants [57]. Fraunhofer ILT built a helicopter part with a 50\% weight reduction due to the internal 316L lattice structures [32]. Wang et al. [58] printed a customized guide to precisely tighten screws in backbone surgeries.

Just like titanium and stainless steel, cobalt-chromium alloys have been extensively used in biomedical [59], automotive, and aerospace fields [60]. CoCr alloys are widely used for the fabrication of dental devices due to corrosion resistance, ductility, and strength suitable for this purpose [61]. The high hardness and melting point make this material difficult to process in dental laboratories, so the PBF-LB process became a good technology to process CoCr. Lastly, $\mathrm{CoCr}$ does not present any allergic or carcinogenic hazard in comparison with other metals like nickel and beryllium [62]. Averyanova et al. [63] stated that PBF-LB is a suitable technique to build dental crowns and bridges with good geometrical accuracy and adequate mechanical properties. Revilla Leon et al. [64] printed and implanted a CoCr maxilla framework on an edentulous patient.

Aluminum alloys are difficult to process via PBF-LB due to poor powder fluidity, laser reflectivity, and oxidation [65]. The PBF-LB process induces a non-equilibrium solidification that increases the solid solution limit of the alloy in the matrix, making it harder to obtain the desired mechanical properties [66]. Nevertheless, aluminum alloys have low density and high strength, making this material the most used structural material with iron and steel [66]. Moreover, when processed, some alloys can present a better corrosion resistance than the wrought [67]. The majority of the alloys used in PBF-LB are based on commercial grade alloys [66]. The most studied aluminum alloys for PBF-LB are Al-Si alloys, in particular, Al-Si10-Mg [68], a near eutectic alloy mostly used for aerospace and automotive applications [69]. For example, Bugatti installed a PBF-LB Al-Si10-Mg bracket with an integrated cooling system on the Chiron to reduce the heat transmission [70]. Ho et al. [71], instead, produced airfoil heat sinks with different fins' shapes.

Nickel-based alloys are another group of materials suitable for PBF-LB. They can reach a relative density near to $100 \%$ and often present a UTS higher than the cast. Nickel alloys have high corrosion resistance, high fatigue resistance, good weldability [72], and a good surface finish with a roughness below $10 \mu \mathrm{m}$. It has been observed that different scanning strategies can generate different grain structures and that microstructural anomalies result from localized shrinkages and stresses, so the proper process parameters must be chosen [73]. The most studied family is Inconel, super alloys used in high-temperature application [47]. For example, Soller et al. [74] developed an Inconel 718 injector for liquid rocket engines, while Caiazzo et al. [75], with the same material, studied the feasibility of producing a turbine blade.

\subsection{PBF-LB - printers and parameters}

Laser-based powder bed fusion is an additive manufacturing process for the production of objects through layers of metal powder locally melted following the cross sections of the object obtained from a CAD model. Initially used as a rapid prototyping technique, it evolved quickly to a manufacturing process due to the possibility of producing complex geometries, not achievable with the conventional and traditional technologies [76], and almost fully dense parts with no need of further post-processing [38]. The success of the production process is influenced by the parameter set involving laser power, scanning speed, hatch spacing, and layer thickness [30]. The process parameters are linked by the following equation (Eq. 4) [77]:

$E=\frac{P}{v * h * l}$

where $E$ is the energy density $\left(\mathrm{J} / \mathrm{mm}^{3}\right), P$ is the laser power $(\mathrm{W}), v$ is the scanning speed $(\mathrm{mm} / \mathrm{s}), h$ is the hatch spacing $(\mathrm{mm})$, and $l$ is the layer thickness $(\mathrm{mm})$. Generally, an increase of the energy density results in a decreased porosity [78, 79], thus enhancing the mechanical properties.

A typical gap between the CAD model and the as-built structure is related to the actual diameter of the strut that often results larger than the designed one [45]. This outcome is due to the presence of not fully melted powder particles attached to 
the strut. The dimension of the struts is influenced by the process parameters that determine the size of the melt pool but even more by the inclination of the strut in the designed structure [80]. In fact, inclined struts lean on loose powder with a lower thermal conductivity, and consequently, the struts orthogonal to the building direction are the most affected ones [80]. Nonetheless, the top-facing surfaces of the struts are also affected by this phenomenon, but in a less critical way [41]. Another factor influencing the strut size is the staircase effect, typical of the layer-by-layer fabrication processes [30]. These phenomena are crucial for the success of a lattice structure printing and therefore must be taken into account during the design phase.

The majority of the printers used in the scientific papers included in this review are developed from four companies that held almost the $60 \%$ of the total amount of available printers. The most used printers and related companies are listed in Table 1.

The process parameters used to fabricate lattice structures differ widely from a paper to another, even considering the same material. This, in addition to the great variety of cell geometries and dimensions and structure porosity and orientation, makes the comparison of different studies ambitious.

\section{Mechanical characterization}

In this section, the testing parameters and outputs of the mechanical characterization of lattice structures will be analyzed. The most significant data have been reported in the following tables. The tables have been designed in order to correlate the material, the cell geometry of the samples, and the characterization parameters to allow a comprehensive comparison between the analyzed researches. Moreover, the tables contain details about any type of further design configurations and treatments applied that may have a direct influence on the mechanical performances. Moreover, the test parameters and the main outputs of the mechanical tests have been reported in

Table 1 Companies and printers most cited in the reviewed works

\begin{tabular}{lll}
\hline Company & Printers & Ref. \\
\hline 3D systems & ProX 200 & {$[8,111]$} \\
& ProX 300 & {$[122]$} \\
& ProX 320 & {$[90,97,100,102,103,106,125]$} \\
SLM solution & SLM 250 HL & {$[82,83,85,95,99,101,117]$} \\
& SLM 280 HL & {$[81,121]$} \\
EOS & M 270 & {$[91]$} \\
& M 280 & {$[88,104,128]$} \\
\multirow{4}{*}{ Renishaw } & M 290 & {$[111,128]$} \\
& AM 250 & {$[98,116,120]$} \\
& AM 400 & {$[13,115]$} \\
\hline
\end{tabular}

order to allow a direct comparison between the test design and the relative outputs, in the absence of a dedicated standard to unify the testing of the lattice mechanical performances. Finally, the most significant curves are graphically reported in order to show the main trends characterizing the behavior of lattice structures subjected to compression, tensile, bending, and fatigue tests.

\subsection{Compression tests}

The compression test is the most used one to characterize lattice structures due to the majority of their applications where the structures are subjected to this type of load. For example, in the biomedical industry, the compression performance of implants, together with the fatigue life and biocompatibility, is the key factor for selecting the right material. The reference standard, although not specific for additive manufacturing specimens, is the ISO 13314-compression test for porous and cellular metals [30]. This standard is specific for a sample with a porosity higher than $50 \%$. The cross section of the specimen can be either cylindrical or rectangular although the cylindrical one is recommended. The dimensions of the specimen, diameter and height in the case of cylindrical samples and length, width, and height in the case of a rectangular geometry, should be set at least 10 times the average pore size and over $10 \mathrm{~mm}$ in length. The ratio between the height and the diameter, or the edge length, should be between 1 and 2. The crosshead speed of the test should be kept constant, and it should be set to obtain an initial strain rate between $10^{-3}$ and $10^{-2} \mathrm{~s}^{-1}$.

The data collected from the reviewed papers are shown in the tables below according to the materials used. Table 2 shows the material, geometry, process design, and compression parameters for titanium samples.

Table 3 shows the material, geometry, process design, and compression parameters for steel samples.

Table 4 shows the material, geometry, process design, and compression parameters for $\mathrm{CoCr}$ samples.

Table 5 shows the material, geometry, process design, and compression parameters for aluminum and Inconel samples.

The reported works have different purposes and demonstrate different results. Several researches compare the mechanical properties and deformation behavior of different cell geometries subjected to the same loads. For example, Kohnen et al. [81] found that the face-centered cubic geometry with vertical struts (FCCZ) has higher strength and elastic modulus than the hollow spherical geometry, making it suitable for structural components. On the other hand, Choy discovered that honeycomb cells have better mechanical performances than cubic cells, with higher space efficiency [82, 83]. Furthermore, Leary concluded that the face-and-bodycentered geometry with vertical struts (FBCCZ) has the highest absolute values of strength and modulus [84] while 


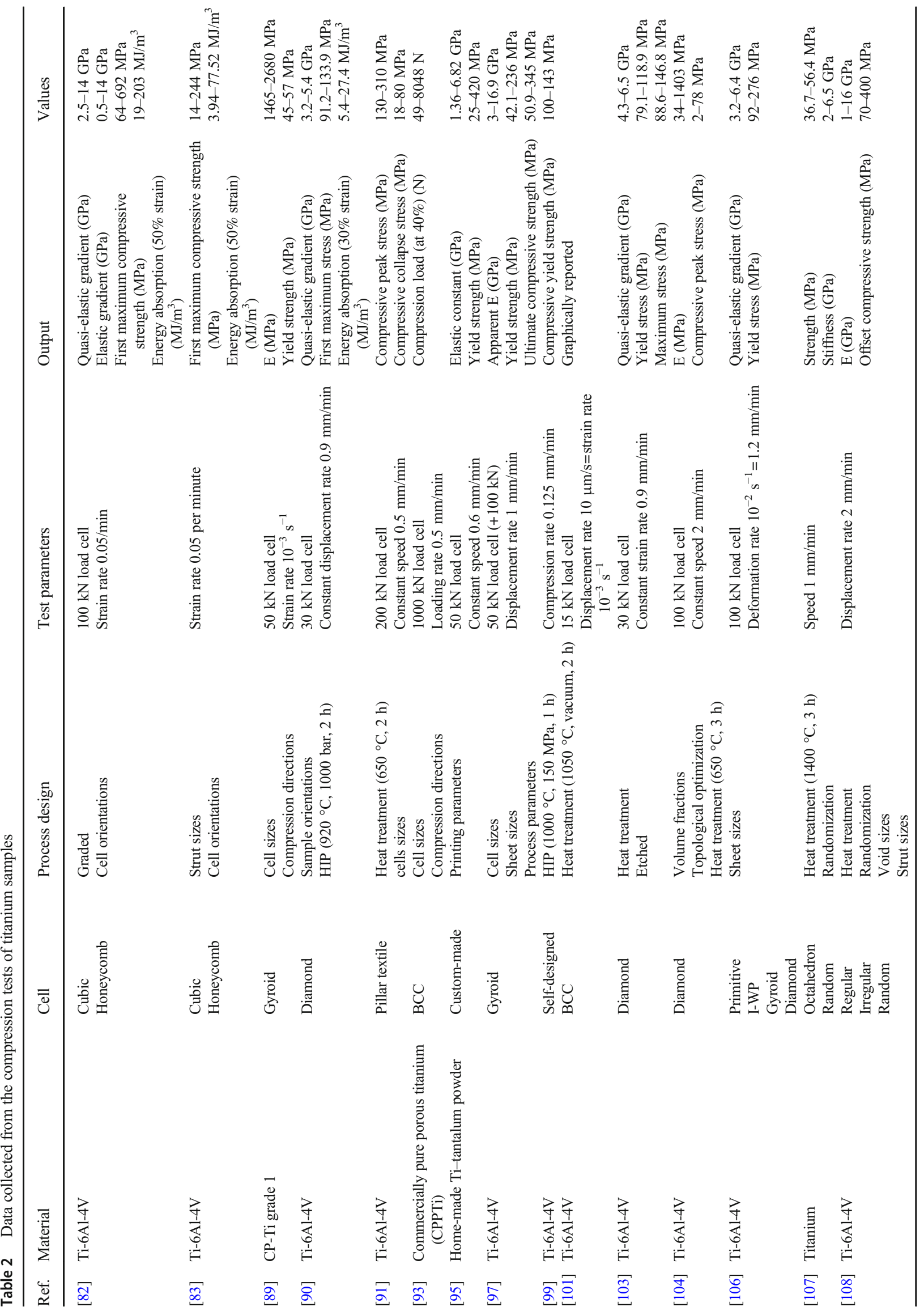




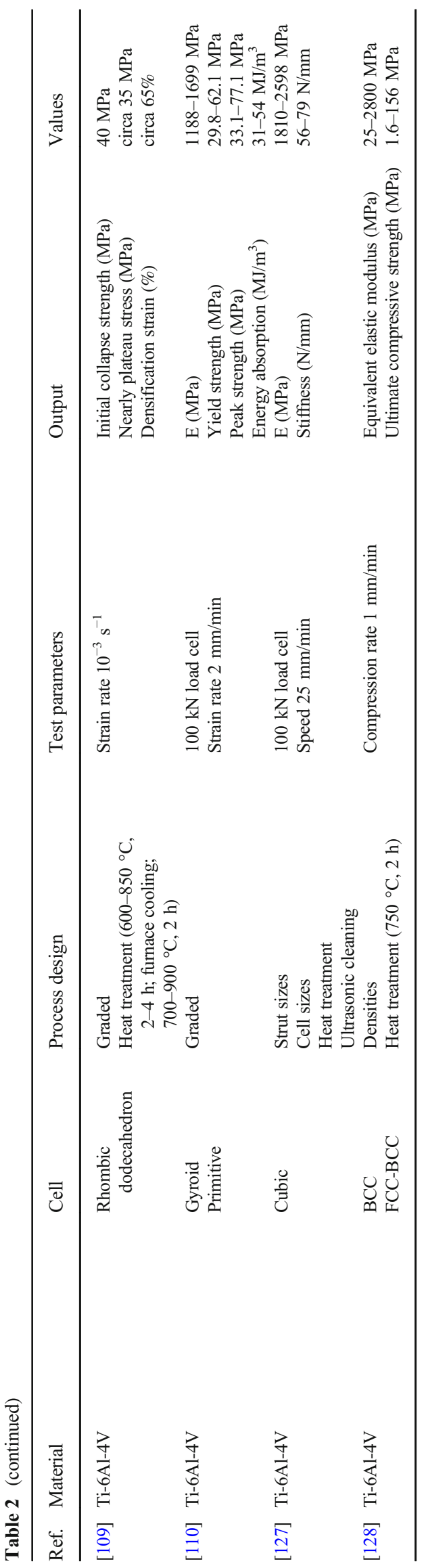

the FCCZ geometry has the best specific strength and modulus compared to other samples [85]. Furthermore, the BBC geometry has been reported to have higher equivalent strength and specific strength than crossing rod unit cell [86], while crossing rod presents higher ultimate and yield strength than circular unit cell [87]. Topological optimization leads usually to cell geometries that often result in improved mechanical performances [88]. For example, Cao et al. [13] introduced a shape parameter in the cross section of the strut that resulted in an increase of the compressive modulus and of the initial yield strength by $79 \%$ and $55 \%$, respectively. Some non-isotropic geometries, characterized by struts placed only in certain directions, have been studied to evaluate the effect of different orientations of print of both the whole specimen and the cell. Yan et al. [12] found that gyroid structures with struts at 0 and $90^{\circ}$ in relation to the building direction offer better mechanical properties than the traditional ones with the struts oriented at $45^{\circ}$. On the other hand, Ataee et al. [89] did not find any influence of the sample orientation on the compression properties of gyroid scaffolds. Besides, Cutolo et al. [90] reported that the load direction in relation to the unit cell orientation has a great effect on the properties of diamond structures, finding an optimal orientation to obtain the strongest samples. Rather than the geometry, some researchers focus on the effect of changing the porosity and volume fraction of the cell by varying the strut dimensions and cell sizes. For example, Campanelli et al. [91] and Amani et al. [92] both found that an increase in volume fraction, or relative density, results in increased mechanical properties. Similar results were achieved by Mager et al. [93] and Ibrahim et al. [94] that recorded a decrease in the compression load and the effective modulus with the increase of the cell size. The printing parameters influence the mechanical properties of lattice structures. Sing et al. [95] and Zhong et al. [96] found that an increase of laser power results in increased mechanical properties. Differently, Kelly [97] did not find great changes on the mechanical properties with refined and optimized parameters. The PBF-LB process can lead to complications such as undesired porosities, defect formation, and residual stresses. Heat treatment and chemical etching have been studied to reduce these issues. Many scientists [98-101] found that a heat treatment reduces the strength of the samples and increases the ductility. On the other hand, Van Hooreweder et al. [102] reported that chemical etching has no influence on mechanical properties while, in another paper, Van Hooreweder et al. [103] found that the different densities of the samples have a strong influence on the mechanical properties making the study of the heat treatment and chemical etching effects hard. Several analyzed works in the biomedical field aimed to obtain structures with properties similar to the natural bones reaching good results [7, 104-106]. For example, cellular randomization techniques have been tested to study their effect on bone ingrowth and mechanical properties. Mullen et al. 


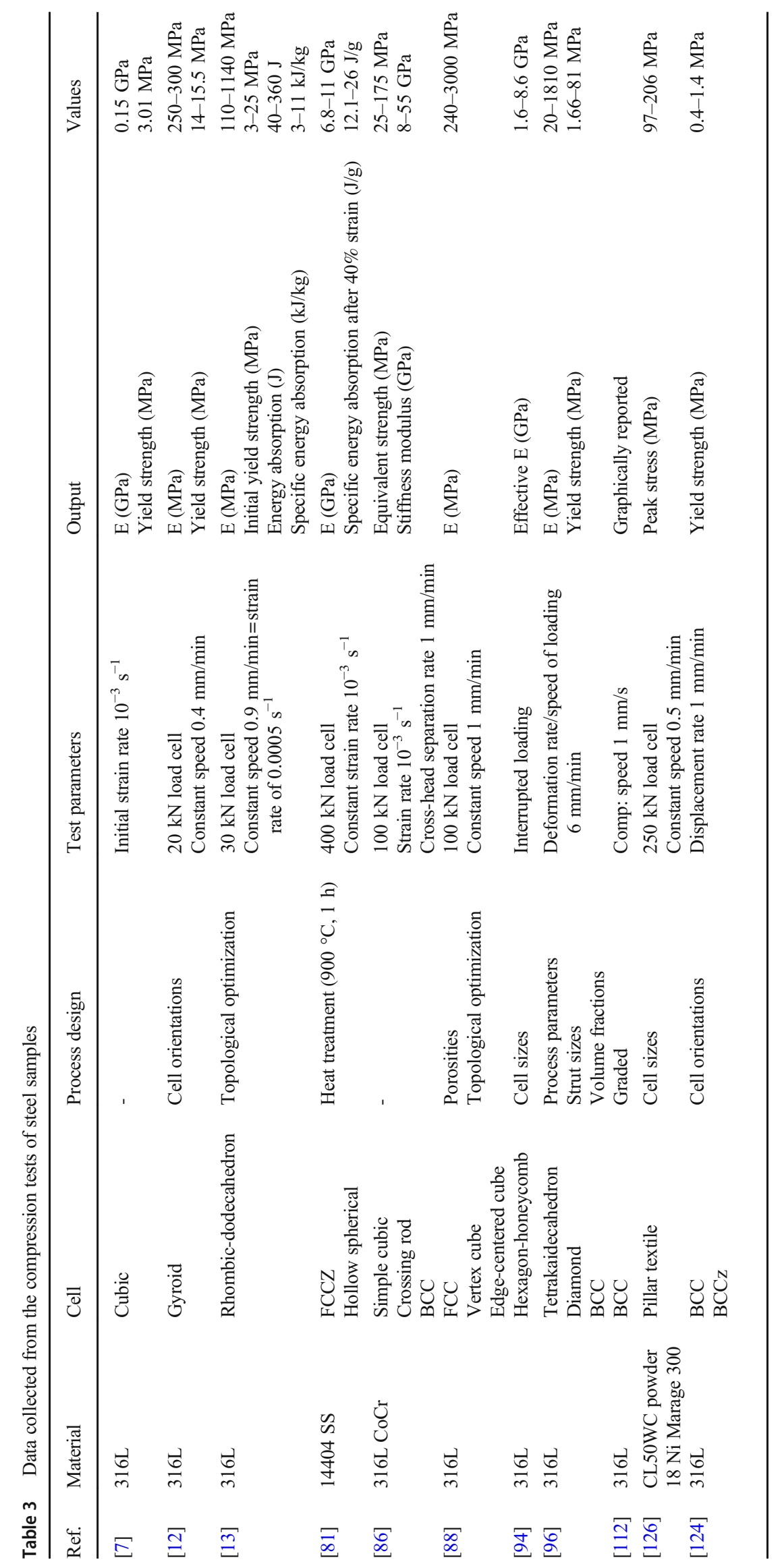




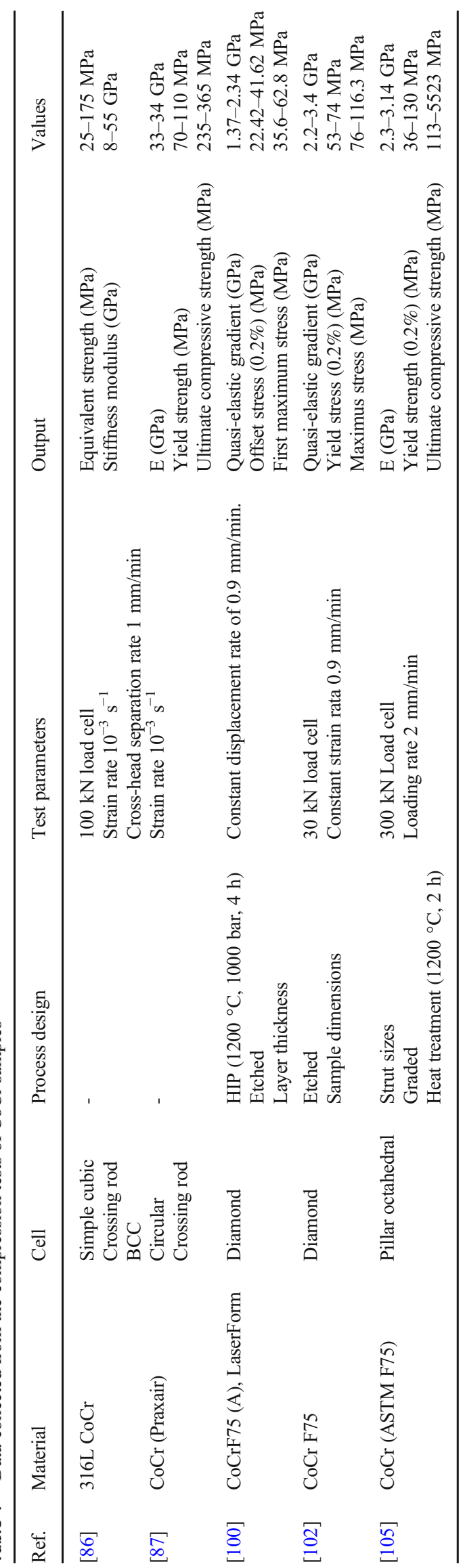

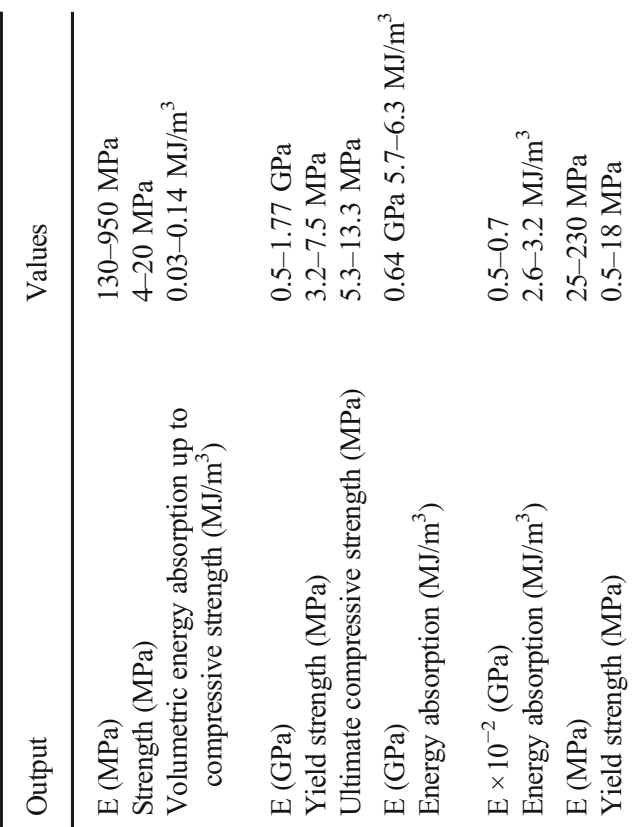

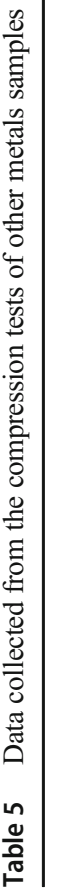

|
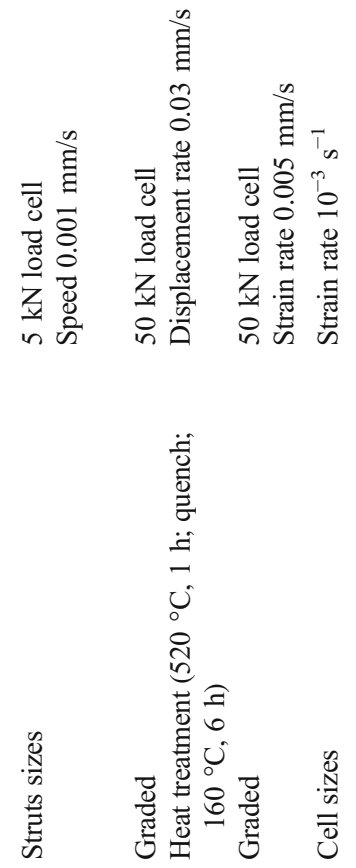

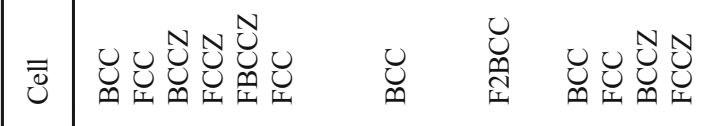

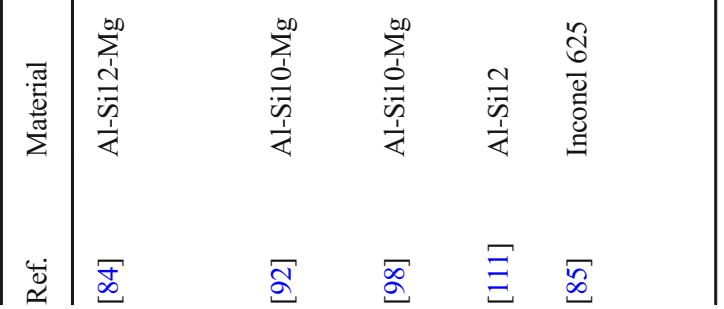


[107] found that a certain level of randomization can improve the mechanical properties reducing the fault planes typical of cellular structures while Raghavendra et al. [108] reported lower values of offset compressive strength and Young modulus for fully random structures. Finally, graded lattice structures have been reported to have better energy absorption capacities [109-111] and higher rate of densification [112].

Examples of resulting compression curves are shown in Fig. 4. The curves show different shapes based on the deformation mechanism that governs the cell. Bending-dominated structures show an elastic region reaching a linear plateau followed by a sudden rise of stress and force values due to densification (Fig. 4a). The stretch-dominated structures present an elastic region culminating in a peak and followed by a wavy post-yielding plateau prior to densification (Fig. 4b, c) [113]. Figure $4 \mathrm{a}$ shows the compression curves of $316 \mathrm{~L} \mathrm{BCC}$ samples with different graded patterns. The general trend is the same for all curves with some small differences. In particular, adding a gradient to the structure increases the relative density resulting in a shorter plateau and in an increased compression force. In fact, the gradient increasing pattern results in higher deformation force and energy. Figure $4 \mathrm{~b}$ shows the compression curves of Ti-6Al-4V primitive samples with different porosities $(\phi)$. As shown, both the yield stress and the plateau stress increase as the porosity decreases. Also, by decreasing the porosity, the plateau becomes shorter and wavier. This waviness is generated by the development of shear lines and built-up stresses. Finally, Fig. $4 \mathrm{c}$ shows the compression curves of Ti-6Al-4V vertically oriented cubic cell samples with different strut sizes. Smaller strut sizes lead to higher porosity resulting in a lower yield and plateau stress. By decreasing the porosity, the samples become more brittle resulting in deeper peaks and valleys shortening the plateau region followed by densification.

In conclusion, the most used load cells ranged from 5 to $400 \mathrm{kN}$, an indication that the mechanical properties of lattice structures can vary depending on the material, geometry, cell size, and density. The speed of the moving crossbar is kept generally very low $(\mathrm{mm} / \mathrm{min})$, leading to a low strain rate as suggested by the ISO 13314 standard. The low strain rate is also suggested to allow the image acquisition to efficiently capture the deformation mechanisms. The most reported, and thus significant, outputs are the compressive Young modulus, the quasi-elastic gradient, and the yield stress. Moreover, the energy absorption is also often crucial due to the application of lattice structures as impact absorber.

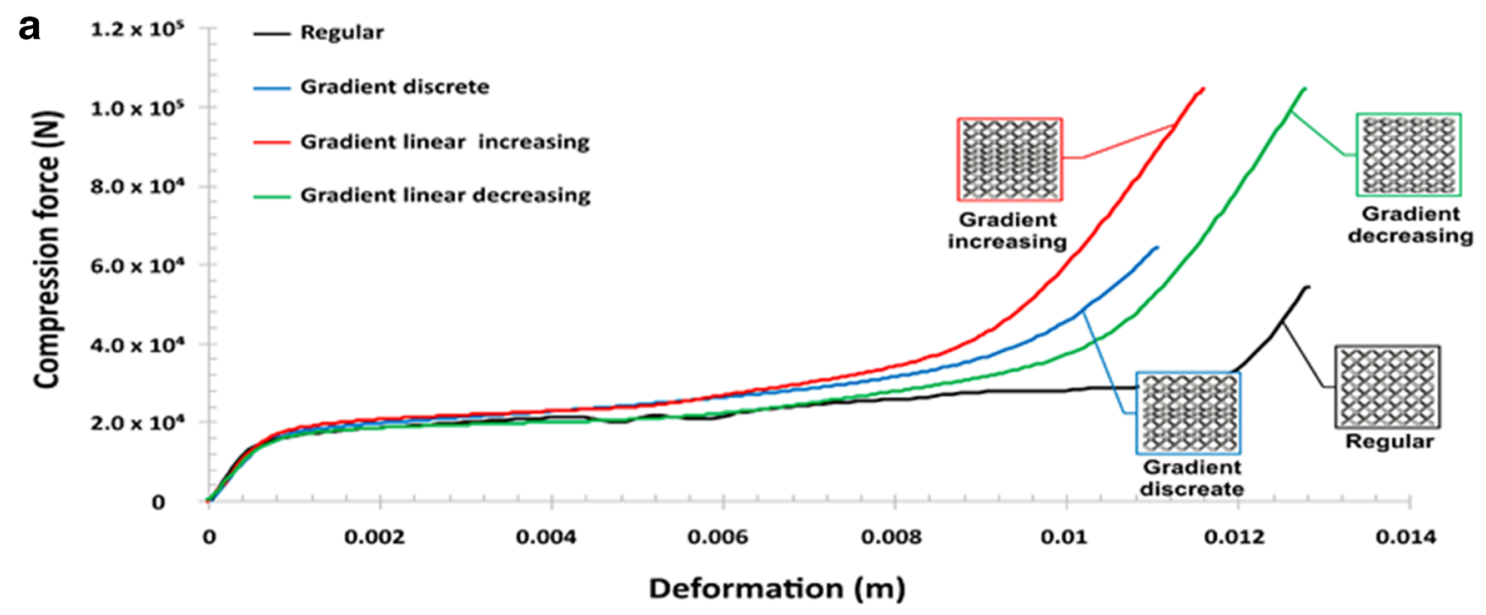

b

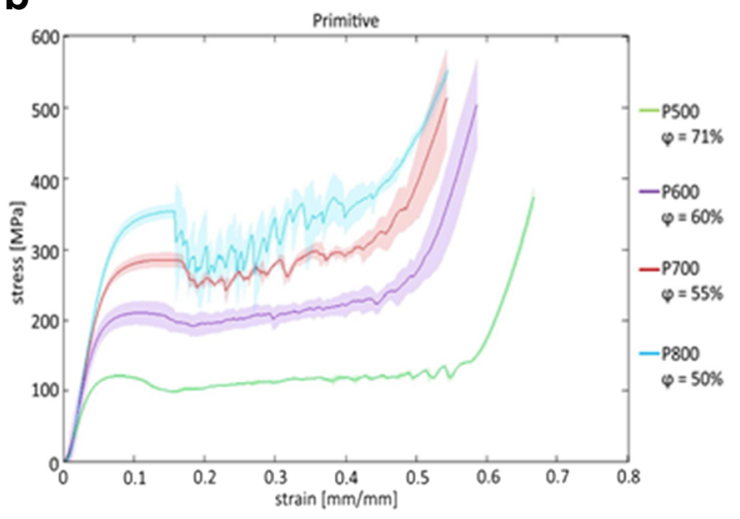

c

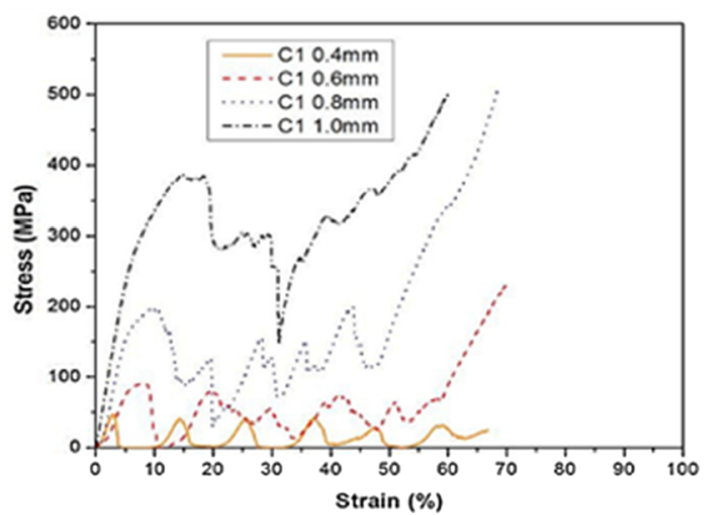

Fig. 4 Compression curves of a 316L BCC samples with different graded patterns [112]. b Ti-6Al-4V primitive samples with different levels of porosity $\phi$; the color shades represent the standard deviation [106]. $\mathbf{c}$ Ti-6Al-4V vertically oriented cubic cell samples with different strut sizes [83] 
Table 6 Data collected from the tensile tests of titanium samples

\begin{tabular}{|c|c|c|c|c|c|c|}
\hline Ref. & Material & Cell & Process design & Test parameters & Output & Values \\
\hline [97] & Ti-6Al-4V & Gyroid & $\begin{array}{l}\text { Cell sizes } \\
\text { Sheet sizes } \\
\text { Process parameters }\end{array}$ & $\begin{array}{l}50 \mathrm{kN} \text { load cell }(+100 \mathrm{kN}) \\
\text { Displacement rate } 1 \mathrm{~mm} / \mathrm{min}\end{array}$ & $\begin{array}{l}\text { Apparent tensile E } \\
\text { (GPa) } \\
\text { Ultimate tensile } \\
\text { strength }(\mathrm{MPa})\end{array}$ & $\begin{array}{l}1.9-17.6 \mathrm{GPa} \\
23.9-121.1 \mathrm{MPa}\end{array}$ \\
\hline [101] & Ti-6Al-4V & $\mathrm{BCC}$ & $\begin{array}{l}\text { Heat treatment }\left(1050^{\circ} \mathrm{C} \text {, }\right. \\
\quad \text { vacuum, } 2 \mathrm{~h})\end{array}$ & $\begin{array}{l}15 \mathrm{kN} \text { load cell } \\
\text { Displacement rate } 10 \mu \mathrm{m} / \mathrm{s}= \\
\text { strain rate } \\
10^{-3} \mathrm{~s}^{-1}\end{array}$ & Graphically reported & \\
\hline [107] & Titanium & $\begin{array}{l}\text { Octahedron } \\
\text { Random }\end{array}$ & $\begin{array}{l}\text { Heat treatment } \\
\quad\left(1400{ }^{\circ} \mathrm{C}, 3 \mathrm{~h}\right) \\
\text { Two levels of randomization }\end{array}$ & Speed $1 \mathrm{~mm} / \mathrm{min}$ & Tensile strength (MPa) & $30.7-49.5 \mathrm{MPa}$ \\
\hline [108] & Ti-6Al-4V & $\begin{array}{l}\text { Simple cubic? } \\
\quad \text { Regular } \\
\text { Irregular } \\
\text { Random }\end{array}$ & $\begin{array}{l}\text { Heat treatment } \\
\text { Randomization } \\
\text { Void sizes } \\
\text { Strut sizes }\end{array}$ & Displacement rate $2 \mathrm{~mm} / \mathrm{min}$ & $\begin{array}{l}\mathrm{E}(\mathrm{GPa}) \\
\text { Ultimate tensile } \\
\text { strength }(\mathrm{MPa})\end{array}$ & $\begin{array}{l}5-45 \mathrm{GPa} \\
50-275 \mathrm{MPa}\end{array}$ \\
\hline [116] & Ti-6Al-4V & $\mathrm{BCC}$ & $\begin{array}{l}\text { Cell sizes } \\
\text { Sample dimensions } \\
\text { Heat treatment }\left(600{ }^{\circ} \mathrm{C}, 3 \mathrm{~h}\right)\end{array}$ & Strain rate $0.01 \mathrm{~mm} / \mathrm{s}$ & $\begin{array}{l}\mathrm{E}(\mathrm{GPa}) \\
\text { Ultimate tensile } \\
\quad \text { strength }(\mathrm{MPa})\end{array}$ & $\begin{array}{l}7-20 \mathrm{GPa} \\
55-189 \mathrm{MPa}\end{array}$ \\
\hline [118] & Ti-6Al-4V & Diamond & $\begin{array}{l}\mathrm{HIP}\left(920^{\circ} \mathrm{C}, 1000 \mathrm{bar}, 2 \mathrm{~h}\right) \\
\text { Surface treatment (SILC } \\
\quad \text { cleaning) }\end{array}$ & Displacement rate $1 \mathrm{~mm} / \mathrm{min}$ & $\begin{array}{l}\text { Tensile E (GPa) } \\
\text { Tensile yield strength } \\
(\mathrm{MPa}) \\
\text { Ultimate tensile } \\
\quad \text { strength }(\mathrm{MPa})\end{array}$ & $\begin{array}{l}10.4-14.1 \mathrm{GPa} \\
146.6-152 \mathrm{MPa} \\
194.9-195.5 \mathrm{MPa}\end{array}$ \\
\hline [119] & $\begin{array}{l}\text { CP-Ti } \\
\quad \text { grade } 2\end{array}$ & Custom made & $\begin{array}{l}\text { Sample dimensions } \\
\text { Sample orientations }\end{array}$ & Constant strain rate $10^{-3} \mathrm{~s}^{-1}$ & $\begin{array}{l}\mathrm{E}(\mathrm{GPa}) \\
\text { Yield stress }(\mathrm{MPa}) \\
\text { Ultimate tensile } \\
\quad \text { strength }(\mathrm{MPa})\end{array}$ & $\begin{array}{l}1.5-3.7 \mathrm{GPa} \\
96.2-133.3 \mathrm{MPa} \\
129.8-143.6 \mathrm{MPa}\end{array}$ \\
\hline [120] & Ti-6Al-4V & Cubic & $\begin{array}{l}\text { Heat treatment } \\
\text { Eurocoating }\end{array}$ & Crosshead speed: $1 \mathrm{~mm} / \mathrm{min}$ & $\begin{array}{l}\text { E (GPa) } \\
\text { Yield strength }(\mathrm{MPa})\end{array}$ & $\begin{array}{l}12.8 \mathrm{GPa} \\
65 \mathrm{MPa}\end{array}$ \\
\hline
\end{tabular}

Table 7 Data collected from the tensile tests of steel samples

\begin{tabular}{|c|c|c|c|c|c|c|}
\hline Ref. & Material & Cell & Process design & Test parameters & Output & Values \\
\hline$[7]$ & $316 \mathrm{~L}$ & Cubic & - & According to CSN EN ISO 6892-1 & $\begin{array}{l}\mathrm{E}(\mathrm{GPa}) \\
\text { Yield strength }(\mathrm{MPa}) \\
\text { Ultimate tensile strength } \\
\quad(\mathrm{MPa})\end{array}$ & $\begin{array}{l}0.12 \mathrm{GPa} \\
3.46 \mathrm{MPa} \\
14.55 \mathrm{MPa}\end{array}$ \\
\hline$[14]$ & $316 \mathrm{~L}$ & Gyroid & $\begin{array}{l}\text { Samples } \\
\text { orientations }\end{array}$ & Constant rate $0.5 \mathrm{~mm} / \mathrm{min}$ & $\begin{array}{l}\text { Yield stress }(\mathrm{MPa}) \\
\text { Ultimate tensile stress } \\
\quad(\mathrm{MPa}) \\
\text { Elongation }(\%)\end{array}$ & $\begin{array}{l}6-13 \mathrm{MPa} \\
19-29 \mathrm{MPa} \\
4-32 \%\end{array}$ \\
\hline$[81]$ & $14404 \mathrm{SS}$ & $\begin{array}{l}\text { FCCZ } \\
\text { Hollow spherical }\end{array}$ & $\begin{array}{l}\text { Heat treatment } \\
\qquad\left(900{ }^{\circ} \mathrm{C}, 1 \mathrm{~h}\right)\end{array}$ & Constant strain rate $10^{-3} \mathrm{~s}^{-1}$ & $\begin{array}{l}\text { Ultimate tensile force }(\mathrm{kN}) \\
\text { Total elongation }(\%)\end{array}$ & $\begin{array}{l}14.5-20.7 \mathrm{kN} \\
4.9-14.8 \%\end{array}$ \\
\hline$[86]$ & $316 \mathrm{~L}$ & $\begin{array}{l}\text { Simple cubic } \\
\text { Crossing rod } \\
\text { BCC }\end{array}$ & - & $\begin{array}{l}100 \mathrm{kN} \text { load cell } \\
\text { Strain rate } 10^{-3} \mathrm{~s}^{-1} \\
\text { Cross-head separation rate } 1 \mathrm{~mm} / \mathrm{min}\end{array}$ & $\begin{array}{l}\text { Equivalent strength (MPa) } \\
\text { Stiffness modulus (GPa) }\end{array}$ & $\begin{array}{l}22-100 \mathrm{MPa} \\
4-22 \mathrm{GPa}\end{array}$ \\
\hline$[96]$ & $316 \mathrm{~L}$ & $\begin{array}{l}\text { Tetrakaidecahedron } \\
\text { Diamond } \\
\text { BCC }\end{array}$ & $\begin{array}{l}\text { Process } \\
\quad \text { parameters } \\
\text { Strut sizes } \\
\text { Volume fractions }\end{array}$ & $\begin{array}{l}\text { Deformation rate/speed of loading } \\
66 \mathrm{~mm} / \mathrm{min}\end{array}$ & $\begin{array}{l}\text { Plateau stress (MPa) } \\
\text { Energy absorption }\left(\mathrm{J} / \mathrm{cm}^{3}\right)\end{array}$ & $\begin{array}{l}2-80 \mathrm{MPa} \\
1-31 \mathrm{~J} / \mathrm{cm}^{3}\end{array}$ \\
\hline$[114]$ & $316 \mathrm{~L}$ & $\begin{array}{l}\text { Truss structure } \\
\text { Octahedral } \\
\text { BCC }\end{array}$ & - & Not reported & $\begin{array}{l}\text { Strength }(\mathrm{MPa}) \\
\text { Highest reached force }(\mathrm{kN})\end{array}$ & $\begin{array}{l}22.5-110 \mathrm{MPa} \\
1.45-7.05 \mathrm{kN}\end{array}$ \\
\hline$[115]$ & $316 \mathrm{~L}$ & $\begin{array}{l}\text { Simple cubic } \\
\text { BCC } \\
\text { Tetragon vertex } \\
\text { Tetragon edge }\end{array}$ & Strut sizes & Load speed $5 \mathrm{~mm} / \mathrm{min}$ & $\mathrm{E}(\mathrm{GPa})$ & $0.84-9.07 \mathrm{GPa}$ \\
\hline [117] & $\begin{array}{r}1.4404 \\
\text { steel }\end{array}$ & Custom-made & Densities & $\begin{array}{l}50 \mathrm{kN} \text { load cell } \\
\text { Testing speed } 0.01-0.02 \mathrm{~mm} / \mathrm{s}\end{array}$ & Maximum force $(\mathrm{N})$ & $535-3800 \mathrm{~N}$ \\
\hline
\end{tabular}


Table 8 Data collected from the tensile tests of other metal samples

\begin{tabular}{|c|c|c|c|c|c|c|}
\hline Ref. & Material & Cell & Process design & Test parameters & Output & Values \\
\hline [87] & $\mathrm{CoCr}$ (Praxair) & $\begin{array}{l}\text { Circular } \\
\text { Crossing rod }\end{array}$ & - & Not reported & $\begin{array}{l}\mathrm{E}(\mathrm{GPa}) \\
\text { Yield strength }(\mathrm{MPa}) \\
\text { Ultimate tensile strength }(\mathrm{MPa})\end{array}$ & $\begin{array}{l}21-27 \mathrm{GPa} \\
75-110 \mathrm{MPa} \\
80-150 \mathrm{MPa}\end{array}$ \\
\hline$[121]$ & Al-Si10-Mg & $\begin{array}{l}\text { Triangular prism } \\
\text { Square prism } \\
\text { Hexagonal prism }\end{array}$ & Cell sizes & $\begin{array}{l}250 \mathrm{kN} \text { load cell } \\
\text { Deformation rate } 1 \mathrm{~mm} / \mathrm{min}\end{array}$ & Tensile effective E (GPa) & $3.4-9.8 \mathrm{GPa}$ \\
\hline
\end{tabular}

\subsection{Tensile test}

To date, international standards for tensile tests of porous or cellular structures are yet to be developed. Although some of the test parameters like the low crossbar speed can be set by taking the compression test as an example, other parameters still remain undefined. For example, the size, the geometry, and the minimum number of unit cell per side of the specimen are chosen arbitrarily without any reliable criteria. Moreover, the transition between the lattice section and the extremities of the samples that act as gripping points is not defined. For these reasons, an international standard regarding the tensile test of porous and cellular structures can lead to more uniform and reliable information. The most reported output of the tensile test is the tensile Young modulus together with the yield stress and ultimate tensile strength. The analyzed data are reported in different tables divided by the target material: Table 6 for titanium, Table 7 for steel, and Table 8 for other metals.

Table 6 shows the material, geometry, process design, tensile parameters, and results for titanium samples.

Table 7 shows the material, geometry, process design, tensile parameters, and results for steel samples.

Table 8 shows the material, geometry, process design, tensile parameters, and results for other metals samples.

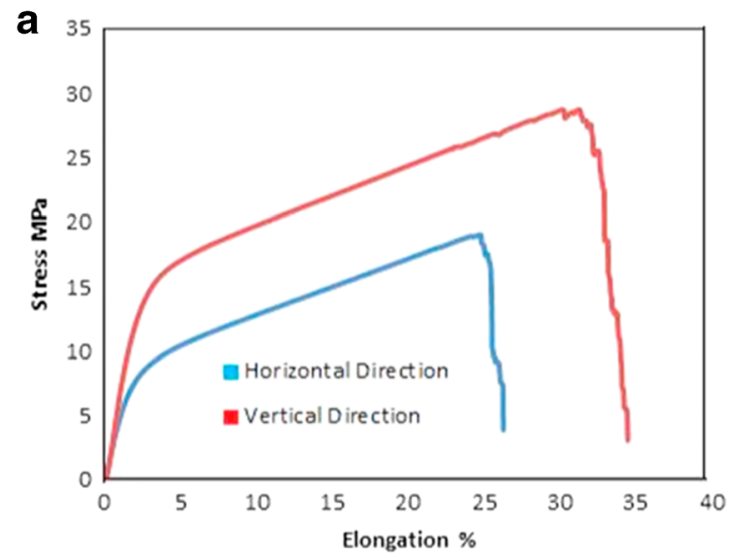

Fig. 5 Tensile curves of $316 \mathrm{~L}$ samples with a gyroid unit cell and different building orientations in relation to the building platform. The horizontal direction has the axis parallel to the building platform; the
One of the main focuses of the evaluated works is the comparison of the performance of different geometries subjected to the tensile test. For example, Kohen et al. [81] reported, as in the case of compression, higher maximum tensile strength in the FCCZ geometry than in the hollow spherical geometry. Liverani et al. [86] compared the BCC, the crossing rod, and the simple cubic geometries, and the crossing rod geometry showed the highest specific strength and stiffness under tension. Again, Kessler et al. [114] reported a higher tensile strength in the truss structure geometry than in the octahedral or BCC geometries. Zhong et al. [96] studied the tensile properties of samples with different geometries and the same volume fraction; the tetrahedral geometry showed a higher ultimate tensile strength than the diamond and BCC geometries. Finally, Hajinys et al. [115] compared the tensile properties of different geometries with three different strut sizes, and the tetragon vertex unit cell with a strut diameter of $0.7 \mathrm{~mm}$ resulted in the stiffest combination. The influence of the cell's parameters is also investigated by several authors. For example, Maskery et al. [116] tested BCC samples with two different cell dimensions and reported that the smallest cell size can maximize the stiffness of the sample. Kelly et al. [97] instead studied gyroid samples with different wall and cell sizes and noted that these two variables have a direct

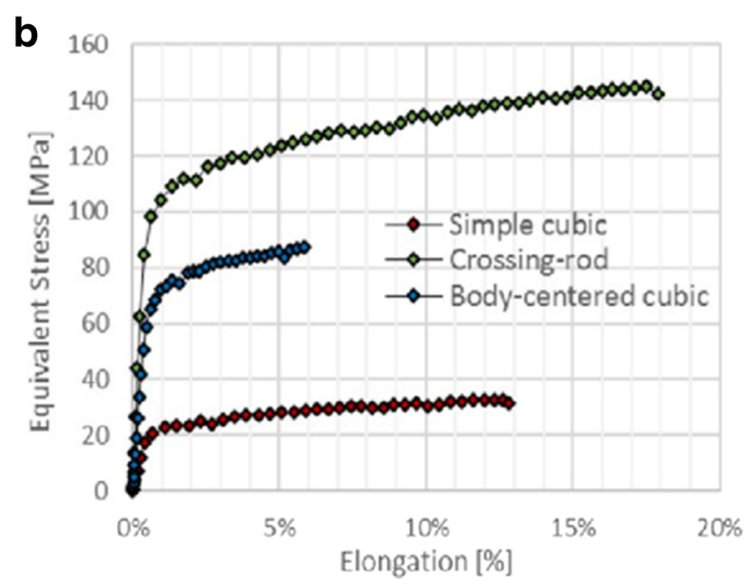

vertical direction has the axis perpendicular to the building platform [14]. b Different unit cell geometries [86] 
and interdependent impact on the mechanical properties, determining the overall porosity of the sample. Similar results were reported by Lober et al. [117] who underlined how the maximum load tolerated by the structure has an exponential dependence from the density. Furthermore, a few works studied the effect of post-processing on the tensile mechanical performances of the lattices. Brenne et al. [101] noted that heat-treated samples bear higher maximum stresses and are able to sustain higher loads, while Kelly et al. [118] found that a surface treatment, such as SILC cleaning, can slightly improve the Young modulus of a Ti-6Al-4V diamond lattice. Other researches focused on the sample's building orientation. For example, Alsalla et al. [14] and Barbas et al. [119] found that vertically built samples have better mechanical tensile properties than horizontal ones. Furthermore, few studies investigated the effect of cell's randomization reaching contrasting results. Muller et al. [107] found that a certain level of randomization improves the mechanical properties while Raghavendra et al. [108] reported regular structures having higher values of strength. Other works tested lattice structures to compare their properties with the natural bone [7, 87] or to validate the related FEM simulation [120, 121].

Two significant examples of tensile stress-strain curves resulting from testing lattice structures are shown in Fig. 5. The presence of a concave elastic region can be a sign of good consolidation and absence of defects [14]. Figure 5a shows the tensile curves of $316 \mathrm{~L}$ gyroid samples with two building orientations in relationship to the building platform. The axis of the sample with the horizontal orientation is parallel to the building platform while the axis of the sample with the vertical orientation is perpendicular to the building platform. Both curves represent the same trend with no sign of brittle failure. However, the vertical-oriented sample has enhanced mechanical properties with higher yield strength, ultimate tensile strength, and elongation. Figure $5 \mathrm{~b}$ shows the tensile curves of $316 \mathrm{~L}$ samples with different unit cell geometries. Again, the curves show the same trend with an elastic region followed by a plastic elongation, a sign of a ductile behavior. The crossing-rod geometry seems to show better properties in terms of both strength and elongation. On the other hand, the BCC is stronger than the simple cubic but with lower elongation.

\subsection{Bending test}

Although not the most studied property, flexural strength is important because in many applications, parts are subjected to this type of load, for example, components for the automotive industry, smart materials, and tissue engineering fields. Bending tests are typically performed in a three-point configuration with a lower span length between 60 and $80 \mathrm{~mm}$ and cylindrically shaped supports. The geometry of the sample is usually rectangular but with a wider range of chosen

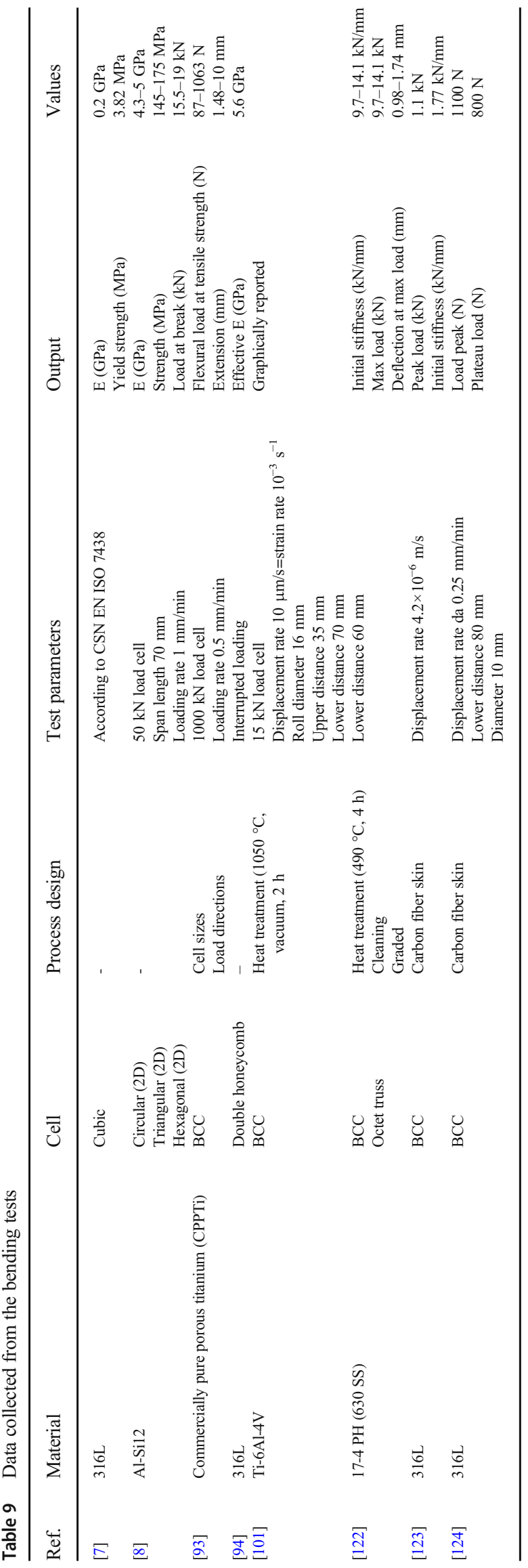



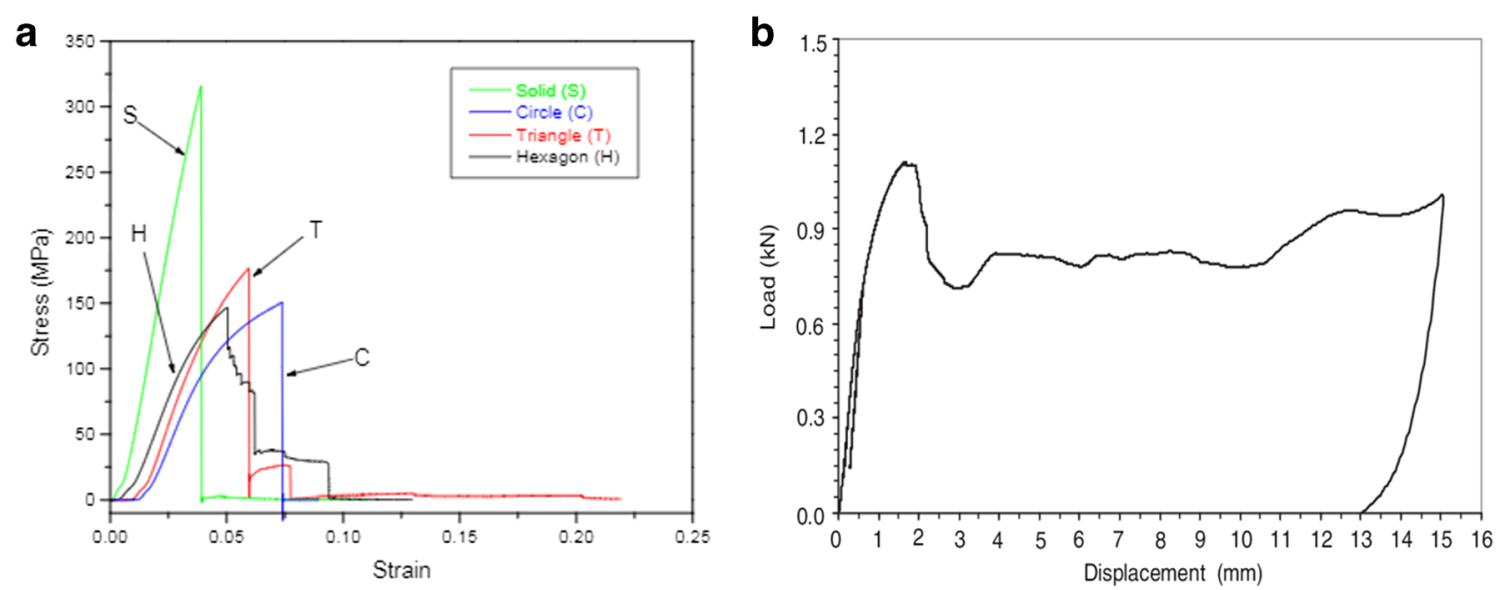

Fig. 6 Bending curves of a Al-Si12 samples with different cell geometries [8] and b 316L BCC sample with carbon skin [124]

dimensions. It is also possible to find a thin layer of full bulk material, called "skin," on the upper and lower faces of the sample. These types of multilayered structures are often studied for aerospace applications and their blast absorbing capabilities. Similarly, to the other type of tests, the displacement rate is kept low. The most reported outputs are the flexural Young modulus, the peak load, and the flexural strength. The data are shown in Table 9.

Rashid et al. [8] found that the triangular geometry has both higher flexural strength and modulus compared to the circular and hexagonal geometries. Kang et al. [122] reported that the multilattice model with a relative density of 0.2 showed the highest stiffness and strength. Mager et al. [93] registered a decrease in the loading force and an increase in the bending extension for bigger cell sizes. Moreover, heat treatment can lead to higher ductility for a Ti-6Al-4V BCC sample with 0.5mm skin as reported by Brenne et al. [101]. Ibrahim et al. [94] performed the flexural test on a double honeycomb lattice structures finding an effective modulus similar to the one obtained from the compression test, suggesting an isotropic behavior of the structure. Finally, Shen et al. [123, 124] studied the skin-core adhesion resistance of multilayered structures under flexural loads.

Two examples of stress-strain curves resulting from lattice structure bending tests are shown in Fig. 6. As shown, the stress either reaches a peak followed by a drop almost to 0

Table 10 Data collected from the fatigue tests

\begin{tabular}{|c|c|c|c|c|c|c|c|}
\hline Ref. & Material & Cell & Process design & Fatigue & $\begin{array}{l}\text { Test } \\
\text { parameters }\end{array}$ & Output & Values \\
\hline [81] & $14404 \mathrm{SS}$ & $\begin{array}{l}\text { FCCZ } \\
\text { Hollow spherical }\end{array}$ & $\begin{array}{l}\text { Heat treatment } \\
\qquad\left(900^{\circ} \mathrm{C}, 1 \mathrm{~h}\right)\end{array}$ & Tensile & $\begin{array}{l}32 \mathrm{~Hz} \\
\mathrm{R} \text { ratio } 0.1\end{array}$ & Fatigue endurance limit $(\mathrm{kN})$ & $1.5 \mathrm{kN}$ \\
\hline [97] & Ti-6Al-4V & Gyroid & $\begin{array}{l}\text { Cell sizes } \\
\text { Sheet sizes } \\
\text { Process parameters }\end{array}$ & $\begin{array}{l}\text { Tensile } \\
\text { Compressive }\end{array}$ & $\begin{array}{l}25 \mathrm{kN} \text { load } \\
\quad \text { cell } \\
10 \mathrm{~Hz} \\
\mathrm{R} 0.1\end{array}$ & $\begin{array}{l}\text { Tensile fatigue strength stress } \\
\text { amplitude }(\mathrm{MPa}) \\
\text { Compressive fatigue strength stress } \\
\text { amplitude (MPa) }\end{array}$ & $\begin{array}{l}1.2-5.4 \mathrm{MPa} \\
5.3-43 \mathrm{MPa}\end{array}$ \\
\hline [99] & Ti-6Al-4V & Self-designed & $\begin{array}{l}\mathrm{HIP}\left(1000^{\circ} \mathrm{C},\right. \\
150 \mathrm{MPa}, 1 \mathrm{~h})\end{array}$ & Compressive & $\begin{array}{l}100 \mathrm{kN} \text { load } \\
\quad \text { cell } \\
10 \mathrm{~Hz} \\
\mathrm{R} 0,1 \\
\text { Sinusoidal } \\
\quad \text { loading }\end{array}$ & Fatigue strength at $10^{6}(\mathrm{MPa})$ & $43-55 \mathrm{MPa}$ \\
\hline [107] & Titanium & $\begin{array}{l}\text { Octahedron }(30 \% \\
\text { random) }\end{array}$ & $\begin{array}{l}\text { Heat treatment } \\
\quad\left(1400^{\circ} \mathrm{C}, 3 \mathrm{~h}\right)\end{array}$ & Compressive & $\begin{array}{l}10 \mathrm{kN} \text { load } \\
\quad \text { cell } \\
6 \mathrm{~Hz} \\
\text { Haversine } \\
\text { wave }\end{array}$ & Strength $(30 \%$ random $)(\mathrm{MPa})$ & $11.1-22.5 \mathrm{MPa}$ \\
\hline [118] & Ti-6Al-4V & Diamond & $\begin{array}{l}\text { HIP }\left(920{ }^{\circ} \mathrm{C},\right. \\
1000 \text { bar, } 2 \mathrm{~h}) \\
\text { Surface treatment } \\
\quad \text { (SILC cleaning) }\end{array}$ & Tensile & $\begin{array}{l}5 \mathrm{~Hz} \\
\mathrm{R} 0.1\end{array}$ & $\begin{array}{l}\text { Maximum stress applied (MPa) } \\
\text { Stress amplitude (MPa) }\end{array}$ & $\begin{array}{l}40 \mathrm{MPa} \\
18 \mathrm{MPa}\end{array}$ \\
\hline
\end{tabular}


indicating a brittle fracture (Fig. 6a) [8] or by a plateau followed by a second increase due to localized compaction (Fig. 6b) [124]. Figure 5a shows the bending curves of Al-Si12 samples with different unit cell geometries. All geometries' curves fail in a brittle way, and circular and triangular geometries drop almost to zero, while hexagonal samples fail more gradually. The triangular geometry shows the highest properties while the circular and hexagonal geometries are almost comparable. Figure $6 \mathrm{~b}$ shows the bending curve of a 316L BCC sample with 4 layers of carbon fiber-reinforced plastic (CFRP) as skin. The curve represents a more ductile behavior with an elastic region culminating in a peak, a drop, and an almost linear plateau. Despite the fact that no delamination of the carbon skin was observed after the application of the bending stress, it seems that the CFRP is not influencing the mechanical response of the BCCs.

\subsection{Fatigue test}

The fatigue tests can be carried out under any stress condition: traction, compression, and bending. The most commonly used is the fatigue test under compression because, as already stated above, several applications are subjected to this type of load. Fatigue performances are very important in the biomedical and aerospace fields where the limits associated with a cyclic loading are very strict [113]. Usually, the shape and size of the specimen follow the same rules as the static tests. The process parameters are quite similar within the considered papers; for example, the load is sinusoidal, the $\mathrm{R}$ is 0.1 , and the number of cycles reaches $10^{6}$. The frequencies vary in a range between 5 and $32 \mathrm{~Hz}$, with 10 and $15 \mathrm{~Hz}$ being the most frequent. The data are shown in Table 10 and Table 11.

As in the cases of compression and traction, and also for the fatigue test, Khonen et al. [81] reported better performances for the FCCZ geometry compared to hollow spherical geometry, failing to a higher load for the same number of cycles. Both Wu et al. [99] and Mullen et al. [107] noted an increase of the fatigue performances after heat treatment of Ti-6Al-4V self-design unit cell and gyroid unit cell, respectively. On the other hand, Kelly et al. [97, 118] reported an increased fatigue life of a gyroid unit cell after process parameter optimization while no effect was observed by the same authors for a diamond cell after surface treatment.

Table 11 Data collected from the fatigue tests that reported output only in graphical form

\begin{tabular}{|c|c|c|c|c|c|}
\hline Ref. & Material & Cell & Process design & Fatigue & Test parameters \\
\hline [100] & CoCr F75 & Diamond & $\begin{array}{l}\text { HIP }\left(1200{ }^{\circ} \mathrm{C}, 1000 \text { bar, } 4 \mathrm{~h}\right) \\
\text { Etched } \\
\text { Layer thickness }\end{array}$ & Compressive & $\begin{array}{l}30 \mathrm{~Hz} \\
\text { R } 10 \\
\text { Sinusoidal loading }\end{array}$ \\
\hline$[101]$ & Ti-6Al-4V & $\mathrm{BCC}$ & Heat treatment $\left(1050{ }^{\circ} \mathrm{C}\right.$, vacuum, $\left.2 \mathrm{~h}\right)$ & $\begin{array}{l}\text { Tensile } \\
\text { Flexural }\end{array}$ & $\begin{array}{l}15 \mathrm{kN} \text { load cell } \\
\text { Tensile: } 10 \mathrm{~Hz} \\
\mathrm{R}-1 \\
\text { Load amplitude } 210 \mathrm{~N}(80 \mathrm{MPa}) \\
\text { Flexural: } 20 \mathrm{~Hz} \\
\text { R } 0.1 \\
\text { Load amplitude } 230 \mathrm{~N} \\
\text { Roll diameter } 16 \mathrm{~mm} \\
\text { Upper distance } 35 \mathrm{~mm} \\
\text { Lower distance } 70 \mathrm{~mm}\end{array}$ \\
\hline$[102]$ & CoCr F75 & Diamond & $\begin{array}{l}\text { Etched } \\
\text { Sample dimensions }\end{array}$ & Compressive & $\begin{array}{l}10 \mathrm{kN} \text { load cell } \\
15 \mathrm{~Hz} \\
\text { R } 0.1 \\
\text { Sinusoidal loading } \\
\text { Fatigue life spectrum } 10^{3}-10^{6} \text { cycles }\end{array}$ \\
\hline$[103]$ & Ti-6Al-4V & Diamond & $\begin{array}{l}\text { Heat treatment } \\
\text { Etched }\end{array}$ & Compressive & $\begin{array}{l}10 \mathrm{kN} \text { load cell } \\
15 \mathrm{~Hz} \\
\text { R } 0.1 \\
\text { Sinusoidal loading }\end{array}$ \\
\hline$[106]$ & Ti-6Al-4V & $\begin{array}{l}\text { Primitive } \\
\text { I-WP } \\
\text { Gyroid } \\
\text { Diamond }\end{array}$ & Sheet sizes & Compressive & $\begin{array}{l}15 \mathrm{~Hz} \\
\mathrm{R} 0.1 \\
\text { Sinusoidal waveform } \\
\text { Max force } 60 \% \text { yield stress }\end{array}$ \\
\hline$[125]$ & $\begin{array}{l}\text { Ti-6Al-4V } \\
\text { CoCr }\end{array}$ & Diamond & $\begin{array}{l}\text { Densities } \\
\text { Heat treatment } \\
\text { Etched }\end{array}$ & Compressive & $\begin{array}{l}10 \mathrm{kN} \text { load cell } \\
15 \mathrm{~Hz} \\
\mathrm{R} 0.1 \text { (constant amplitude sinusoidal) } \\
10^{3}-10^{6} \text { cycles }\end{array}$ \\
\hline
\end{tabular}




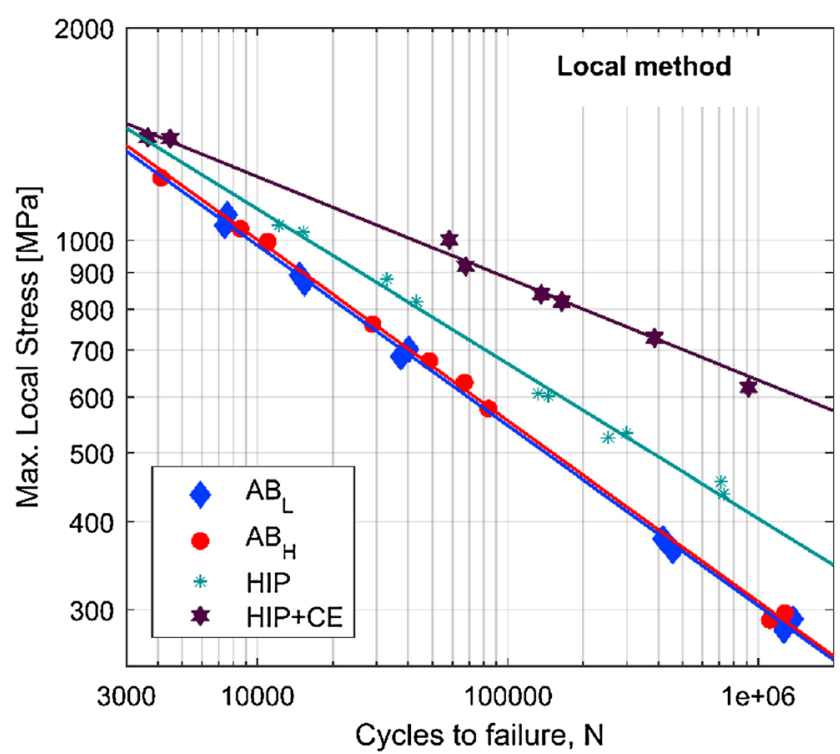

Fig. 7 Effect of heat and surface treatment on the fatigue performance of Ti-6Al-4V samples. AB are as-built samples with low (L) and high (H) relative density, HIP are hot isostatically pressed samples, and $\mathrm{CE}$ are chemically etched samples [125]

Fatigue properties are not very suitable for a numerical and tabular representation, so many of the works reported the results only in graphical form. Van Hooreweder et al. [102, 103, 125] studied the fatigue properties (using a local method) of Ti-6Al-4V diamond unit cell samples subjected to hot isostatic pressing (HIP) followed by chemical etching. The study shows that the fatigue life is improved by the HIP treatment, but an even better result is achieved when chemical etching is added (Fig. 7).

On the other hand, Cutolo et al. [100] reported an increase of the fatigue performances of chemically etched $\mathrm{CoCr}$ samples on a local scale (Fig. 8), while the HIP treatment seemed to be ineffective.
Brenne et al. [101] reported an improved fatigue life in Ti$6 \mathrm{Al}-4 \mathrm{~V}$ samples after heat treatment with a significant increase in the number of cycles to failure at the same displacement amplitude (Fig. 9).

Bobbert et al. [106] studied the influence of apparent density of various triply periodic minimal surface geometries (Fig. 10) on the fatigue properties of the samples. There are different trends as the apparent density increases. The performance of the primitive geometry increases as the apparent density increases, although this design results in the shortest fatigue life. The gyroid geometry shows a performance decrease as the apparent density increases, probably due to the geometry of the unit cell. The fatigue life of the I-WP geometry significantly increases with the increase of the apparent density, achieving high performances. Finally, the diamond geometry reaches the highest fatigue life with the lowest apparent density while for the other values, the results are comparable.

\section{Conclusion}

PBF-LB is an additive manufacturing powder bed fusion system for the production of lattice structures. Lattice structures have been intensively studied due to their low weight, good mechanical properties, and energy absorption capabilities that make them suitable in fields such as aerospace, automotive, and biomedicine. Despite the increasing interest in these types of structures nowadays, the lack of a specified international standard regarding their characterizations forces the researchers to rely on literature or on their experience. The introduction of an international standard would be very useful not only to provide a common procedure that would allow
Fig. 8 Effect of heat and surface treatment on the fatigue performance of CoCr samples. $\mathrm{AB}$ are as-built samples, HIP are hot isostatically pressed samples, and etch are chemically etched samples. The values 30 and $60 \mu \mathrm{m}$ are the layer thicknesses [100]

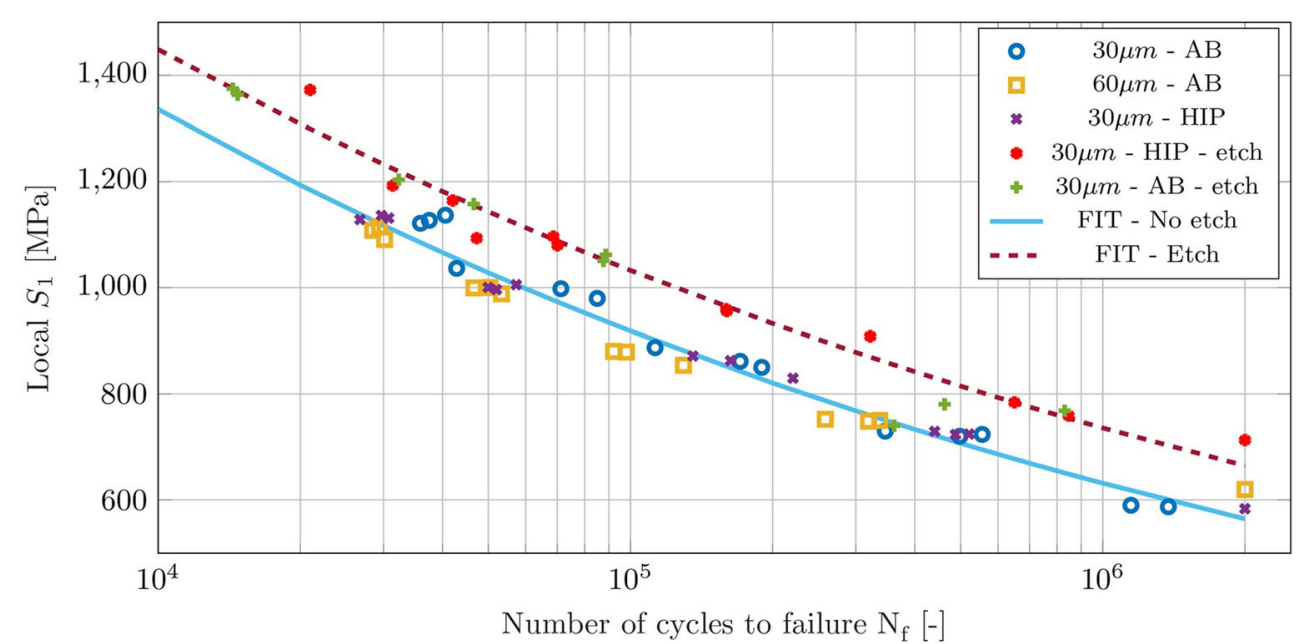


Fig. 9 Effect of heat treatment on the fatigue performance of Ti6Al-4V BCC sample [101]

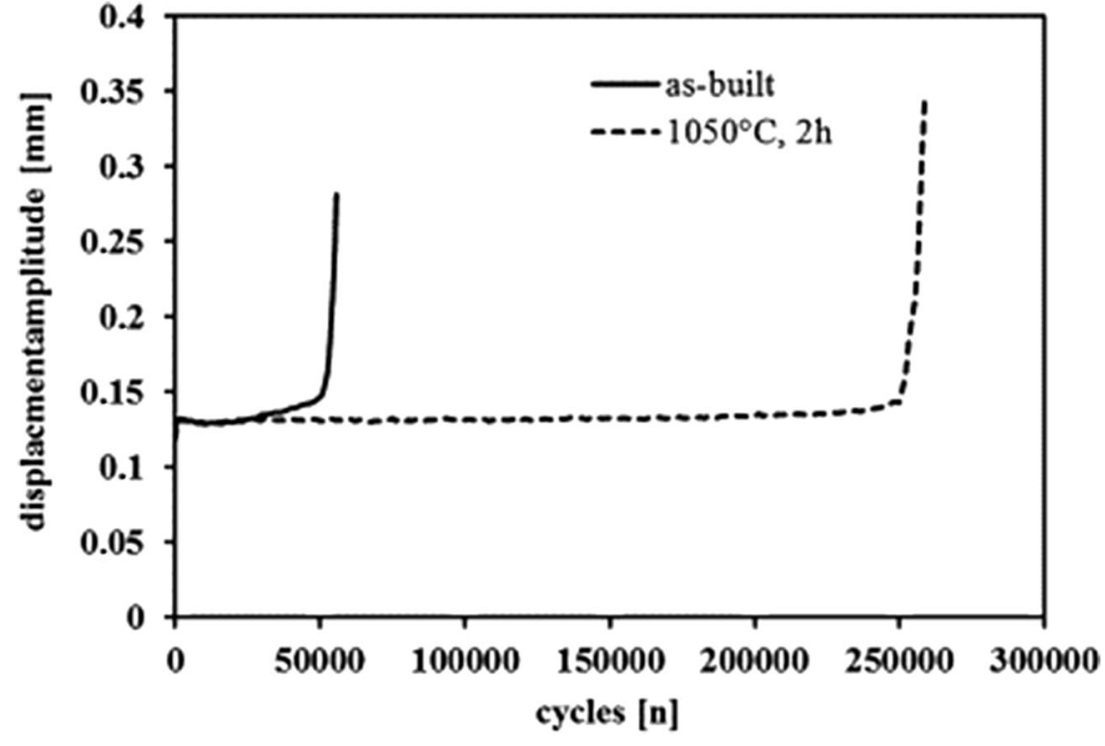

the comparison of results but also to certify the possible applications, without leaving the outcomes only to research purposes. This review merged a large number of data concerning the production and testing of lattice structures. It gives a wide perspective on all the variables that must be taken into consideration when dealing with these types of structures. Furthermore, it gathers the parameters used by AM researchers to test lattice samples, providing a possible guideline to scientists and industries with different goals in the AM sector. The novelty of this review lays in the collection of a large number of data on the mechanical characterization of lattice structures to understand the presence of methodologies used transversely by various researchers, the outputs that are most collected, and the target applications of the works focused on lattice structures. In addition, various information such as material, cell geometry, and process design have been collected in order to relate them to the test results. The main considerations are the following:

- Many researchers followed the ISO 13314_compression test for porous and cellular metals-for the compression test. Although it is not specific for additive manufacturing samples, it provides good guidelines for the
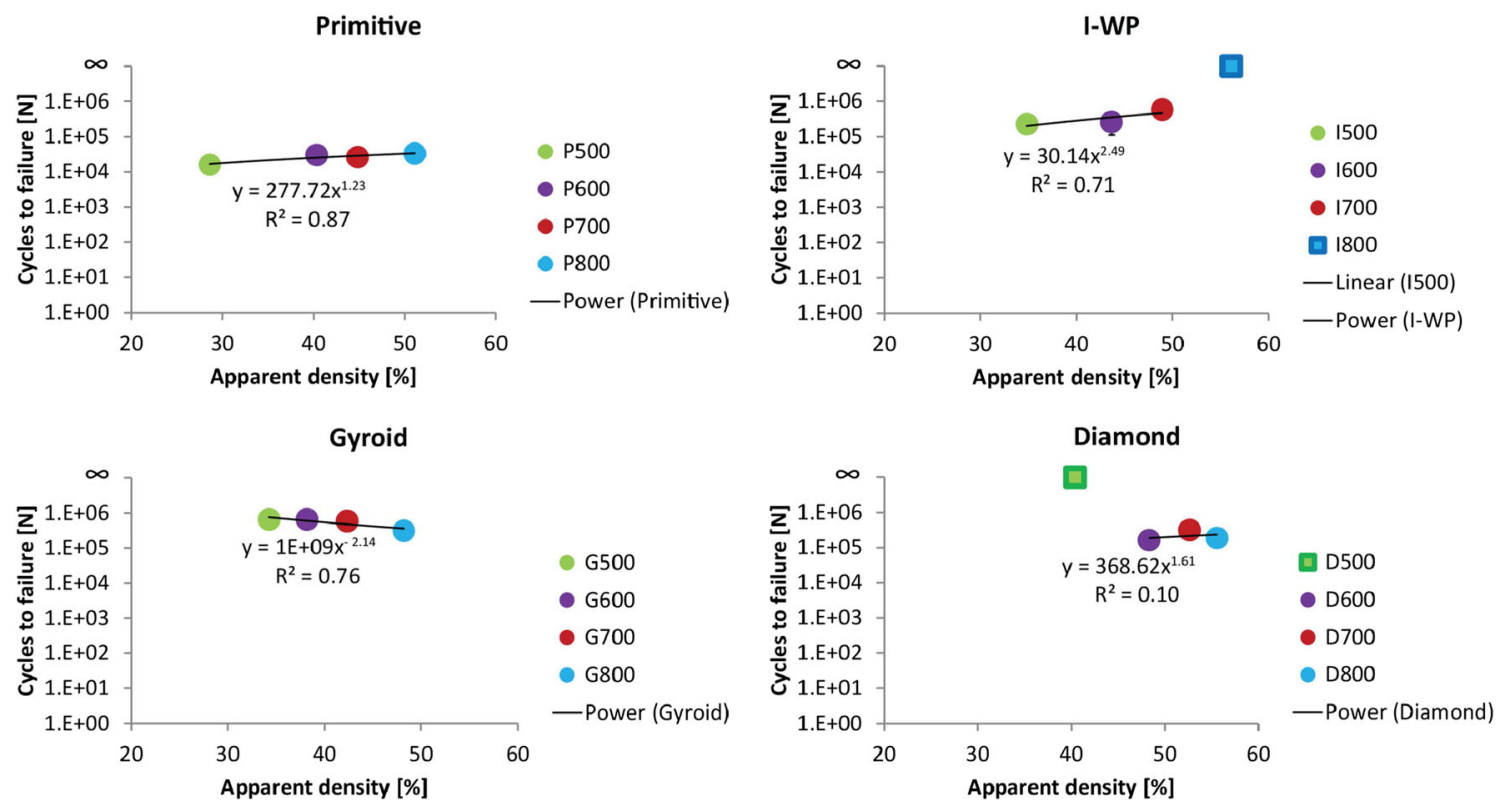

Fig. 10 Effect of different apparent densities on the fatigue performance of triply periodic minimal surface Ti-6Al-4V samples. The squares in the graphs mean the samples reached $10^{6}$ cycles without failing [106] 
Table 12 Most common parameters and outputs used in the reviewed literature

\begin{tabular}{|c|c|c|c|c|c|}
\hline & Sample & Load cell & Strain rate & Outputs & $\begin{array}{l}\text { Frequency } \\
\text { R-ratio } \\
\text { Wave form }\end{array}$ \\
\hline Compression & Prismatic/cylindrical & $30-100 \mathrm{kN}$ & $\begin{array}{l}10^{-3} \mathrm{~s}^{-1} \\
0.5-2 \mathrm{~mm} / \mathrm{min}\end{array}$ & $\begin{array}{l}\text { Young's modulus } \\
\text { Quasi-elastic gradient } \\
\text { Yield stress }\end{array}$ & - \\
\hline Tensile & Prismatic/cylindrical & $50 \mathrm{kN}$ & $\begin{array}{l}10^{-3} \mathrm{~s}^{-1} \\
0.1-2 \mathrm{~mm} / \mathrm{min}\end{array}$ & $\begin{array}{l}\text { Young's modulus } \\
\text { Yield stress } \\
\text { Ultimate tensile strength }\end{array}$ & - \\
\hline Bending & Prismatic & $15-1000 \mathrm{kN}$ & $\begin{array}{l}10^{-3} \mathrm{~s}^{-1} \\
0.25-1 \mathrm{~mm} / \mathrm{min}\end{array}$ & $\begin{array}{l}\text { Young's modulus } \\
\text { Peak load } \\
\text { Flexural strength }\end{array}$ & - \\
\hline Fatigue & Cylindrical/prismatic & $10-25 \mathrm{kN}$ & - & $\begin{array}{l}\text { Fatigue strength } \\
\text { Graphical }\end{array}$ & $\begin{array}{l}10-15 \mathrm{~Hz} \\
0.1-10 \\
\text { Sinusoidal }\end{array}$ \\
\hline
\end{tabular}

characterization of lattice structures (i.e., the geometry of the sample with related proportions and recommended strain rate).

- The geometry of the samples chosen for tensile and bending varies arbitrarily: cyclic samples follow the shape of the quasi-static tests. In this case, the strain rate is kept low, probably inspired by the compression tests.

- The most reported output for the quasi-static tests is the Young modulus, the yield stress, and the ultimate stress, while for the fatigue test, the graphical representation is preferred and often the quantitative data are not reported.

- Different variables have been taken into account for the production of lattice structures: geometry, dimensions, and post-production treatments. Therefore, several works studied their influence on the mechanical properties of different samples. A complete knowledge of these factors is fundamental to understanding the full potential of these structures.

- It can be noted that an increase in sample density leads to an increase in the main mechanical properties. Further methods used to expand the range of obtainable values are heat treatment and grading of the sample, techniques that are quite effective on properties such as ductility and energy absorption.

The most common test parameters and outputs for every test used in the reviewed literature are listed in Table 12.

This data can be considered a starting point for a future study aiming to develop a new standard method. The presented test parameters are all similar because they are inspired by the compression tests, but this strategy is not necessarily optimal for each type of test which can have a very different goal from the others. An additional point to focus on is the size and proportions of the samples, at the moment too different from each other and therefore with a different effect on the final result.

To conclude, the authors highlight that the number of works focusing on the tensile, bending, and fatigue tests is relatively low compared to the ones focusing on the compression tests. A bigger number of studies are therefore needed to put a more solid base to allow a necessary comparison between different studies. Moreover, the authors suggest a critical evaluation of the mechanical test parameters to demonstrate their effectiveness and usefulness for the characterization of lattice structures and identify any possible modification to make the parameters more functional based on the final application.

Code availability Not applicable.

Funding Open Access funding provided by Università degli Studi di Brescia.

Data availability Not applicable.

\section{Declarations}

Fundings This research did not receive any specific grant from funding agencies in the public, commercial, or not-for-profit sectors.

Conflict of interest The authors declare no conflict of interest.

Availability of data and material Not applicable.

Code availability Not applicable.

Open Access This article is licensed under a Creative Commons Attribution 4.0 International License, which permits use, sharing, adaptation, distribution and reproduction in any medium or format, as long as you give appropriate credit to the original author(s) and the source, provide a link to the Creative Commons licence, and indicate if changes were made. The images or other third party material in this article are included in the article's Creative Commons licence, unless indicated otherwise in a credit line to the material. If material is not included in the article's Creative Commons licence and your intended use is not permitted by statutory regulation or exceeds the permitted use, you will need to obtain permission directly from the copyright holder. To view a copy of this licence, visit http://creativecommons.org/licenses/by/4.0/. 


\section{References}

1. Thompson MK, Moroni G, Vaneker T, Fadel G, Campbell RI, Gibson I, Bernard A, Schulz J, Graf P, Ahuja B, Martina F (2016) Design for additive manufacturing: trends, opportunities, considerations, and constraints. CIRP Ann Manuf Technol 65: 737-760. https://doi.org/10.1016/j.cirp.2016.05.004

2. DebRoy T, Wei HL, Zuback JS, Mukherjee T, Elmer JW, Milewski JO, Beese AM, Wilson-Heid A, de A, Zhang W (2018) Additive manufacturing of metallic components - process, structure and properties. Prog Mater Sci 92:112-224

3. Yakout M, Elbestawi MA, Veldhuis SC (2018) A review of metal additive manufacturing technologies. Solid State Phenom 278:1-14

4. Wohlers Associates (2010) What is additive manufacturing?. https://wohlersassociates.com/additive-manufacturing.html

5. Bhavar V, Kattire P, Patil V et al (2014) A review on powder bed fusion technology of metal additive manufacturing. In: 4th International conference and exhibition on Additive Manufacturing Technologies-AM-2014

6. Soiel International (2017) Produzione additiva: a che punto siamo. https://www.soiel.it/news/dettaglio/produzione-additiva-a-chepunto-siamo

7. Čapek J, Machová M, Fousová M et al (2016) Highly porous, low elastic modulus 316L stainless steel scaffold prepared by selective laser melting. Mater Sci Eng C 69:631-639. https://doi.org/10. 1016/j.msec.2016.07.027

8. Rahman Rashid RA, Mallavarapu J, Palanisamy S et al (2017) A comparative study of flexural properties of additively manufactured aluminium lattice structures. Mater Today: Proc 4: 8597-8604

9. Ginestra P, Ceretti E, Lobo D, Lowther M, Cruchley S, Kuehne S, Villapun V, Cox S, Grover L, Shepherd D, Attallah M, Addison O, Webber M (2020) Post processing of 3D printed metal scaffolds: a preliminary study of antimicrobial efficiency. Procedia Manuf 47:1106-1112

10. Horn TJ, Harrysson OLA (2012) Overview of current additive manufacturing technologies and selected applications. Sci Prog 95(3): 255-282. https://doi.org/10.3184/003685012X13420984463047

11. Nagesha BK, Dhinakaran V, Varsha Shree M (2020) Review on characterization and impacts of the lattice structure in additive manufacturing. Mater Today: Proc 21:916-919. https://doi.org/ 10.1016/j.matpr.2019.08.158

12. Yan C, Hao L, Hussein A, Young P, Raymont D (2014) Advanced lightweight 316L stainless steel cellular lattice structures fabricated via selective laser melting. Mater Des 55:533-541. https://doi. org/10.1016/j.matdes.2013.10.027

13. Cao X, Duan S, Liang J, Wen W, Fang D (2018) Mechanical properties of an improved 3D-printed rhombic dodecahedron stainless steel lattice structure of variable cross section. Int J Mech Sci 145:53-63. https://doi.org/10.1016/j.jimecsci.2018.07.006

14. Alsalla H, Hao L, Smith C (2016) Fracture toughness and tensile strength of $316 \mathrm{~L}$ stainless steel cellular lattice structures manufactured using the selective laser melting technique. Mater Sci Eng A 669:1-6. https://doi.org/10.1016/j.msea.2016.05.075

15. Mines RAW, Tsopanos S, Shen Y, Hasan R, McKown ST (2013) Drop weight impact behaviour of sandwich panels with metallic micro lattice cores. Int J Impact Eng 60:120e132-120e132. https:// doi.org/10.1016/j.ijimpeng.2013.04.007

16. Chantarapanich N, Laohaprapanon A, Wisutmethangoon S, Jiamwatthanachai P, Chalermkarnnon P, Sucharitpwatskul S, Puttawibul P, Sitthiseripratip K (2014) Fabrication of threedimensional honeycomb structure for aeronautical applications using selective laser melting: a preliminary investigation. Rapid Prototyp J 20(6):551-558. https://doi.org/10.1108/RPJ-08-2011-0086
17. Bici M, Brischetto S, Campana F, Ferro CG, Seclì C, Varetti S, Maggiore P, Mazza A (2018) Development of a multifunctional panel for aerospace use through SLM additive manufacturing. Procedia CIRP 67:215-220. https://doi.org/10.1016/j.procir. 2017.12.202

18. Miller DL, Kersten G, Frost WA (2014) Systems and methods for protecting a flight recorder, US 8,723,057 B2

19. Büşra A, Ali RY (2020) Optimum design of automobile components using lattice structures for additive manufacturing. Mater Test 62(6):633-639

20. Fiorentino A, Zarattini G, Pazzaglia U et al (2013) Hip prosthesis design. Market analysis, new perspectives and an innovative solution. Procedia CIRP 5:310-314

21. Ginestra PS, Ceretti E, Fiorentino A (2016) Potential of modeling and simulations of bioengineered devices: endoprostheses, prostheses and orthoses. Proc Inst Mech Eng H: J Eng Med 230(7): 607-638

22. 3D Printing Media Network (2019) Joseph Spine surgeons implant world's first 3D printed Aries L Titanium Spinal Implant. https://www.3dprintingmedia.network/joseph-spine-surgeonsimplant-worlds-first-3d-printed-aries-1-titanium-spinal-implant/

23. Limmahakhun S, Oloyede A, Chantarapanich N, Jiamwatthanachai P, Sitthiseripratip K, Xiao Y, Yan C (2017) Alternative designs of load-sharing cobalt chromium graded femoral stems. Mater Today Commun 12:1-10. https://doi.org/10. 1016/j.mtcomm.2017.05.002

24. Hazlehurst KB, Wang CJ, Stanford M (2014) An investigation into the flexural characteristics of functionally graded cobalt chrome femoral stems manufactured using selective laser melting. Mater Des 60:177-183. https://doi.org/10.1016/j.matdes.2014.03. 068

25. España FA, Balla VK, Bose S, Bandyopadhyay A (2010) Design and fabrication of CoCrMo alloy based novel structures for load bearing implants using laser engineered net shaping. Mater Sci Eng C 30:50-57. https://doi.org/10.1016/j.msec.2009.08.006

26. Wang HV, Johnston SR, Rosen DW (2006) Design of a graded cellular structure for an acetabular hip replacement component. Proceedings of The Seventeenth Solid Freeform Fabrication Symposium

27. Arabnejad S, Johnston B, Tanzer M, Pasini D (2017) Fully porous 3D printed titanium femoral stem to reduce stress-shielding following total hip arthroplasty. J Orthop Res 35:1774-1783. https:// doi.org/10.1002/jor.23445

28. Murr LE, Amato KN, Li SJ, Tian YX, Cheng XY, Gaytan SM, Martinez E, Shindo PW, Medina F, Wicker RB (2011) Microstructure and mechanical properties of open-cellular biomaterials prototypes for total knee replacement implants fabricated by electron beam melting. J Mech Behav Biomed Mater 4:13961411. https://doi.org/10.1016/j.jmbbm.2011.05.010

29. Wauthle R, van der Stok J, Amin Yavari S, van Humbeeck J, Kruth JP, Zadpoor AA, Weinans H, Mulier M, Schrooten J (2014) Additively manufactured porous tantalum implants. Acta Biomater 14:217-225. https://doi.org/10.1016/j.actbio.2014.12. 003

30. Sing SL, Miao Y, Wiria FE, Yeong WY (2016) Manufacturability and mechanical testing considerations of metallic scaffolds fabricated using selective laser melting: a review. Biomed Sci Eng. https://doi.org/10.4081/bse.2016.11

31. Nazir A, Abate KM, Kumar A, Jeng JY (2019) A state-of-the-art review on types, design, optimization, and additive manufacturing of cellular structures. Int J Adv Manuf Technol 104:3489-3510. https://doi.org/10.1007/s00170-019-04085-3

32. Tao W, Leu MC Design of lattice structures for additive manufacturing. https://doi.org/10.1109/ISFA.2016.7790182

33. De Pasquale G, Montemurro M, Catapano A et al (2018) Cellular structures from additive processes: design, homogenization and 
experimental validation. Procedia Struct Integrity 8:75-82. https:// doi.org/10.1016/j.prostr.2017.12.009

34. Leonardi F, Graziosi S, Casati R et al (2019) Additive manufacturing of heterogeneous lattice structures: an experimental exploration. International Conference on Engineering Design, ICED19 https://doi.org/10.1017/dsi.2019.71

35. Refai K, Montemurro M, Brugger C, Saintier N (2019) Determination of the effective elastic properties of titanium lattice structures. Mech Adv Mater Struct 27:1966-1982. https://doi.org/ 10.1080/15376494.2018.1536816

36. Mazur M, Leary M, McMillan M et al (2017) Mechanical properties of Ti6Al4V and AlSi12Mg lattice structures manufactured by selective laser melting (SLM). Laser Addit Manuf. https://doi. org/10.1016/B978-0-08-100433-3.00005-1

37. Qi D, Yu H, Liu M, Huang H, Xu S, Xia Y, Qian G, Wu W (2019) Mechanical behaviors of SLM additive manufactured octet-truss and truncated-octahedron lattice structures with uniform and taper beams. Int J Mech Sci 163:105091. https://doi.org/10.1016/j. ijmecsci.2019.10509

38. Yan C, Hao L, Hussein A, Raymont D (2012) Evaluations of cellular lattice structures manufactured using selective laser melting. Int J Mach Tool Manu 62:32-38. https://doi.org/10.1016/j. ijmachtools.2012.06.002

39. Yuan L, Ding S, Wen C (2019) Additive manufacturing technology for porous metal implant applications and triple minimal surface structures: a review. Bioactive Mater 4:56-70. https://doi.org/ 10.1016/j.bioactmat.2018.12.003

40. Mahmoud D, Elbestawi MA (2019) Selective laser melting of porosity graded lattice structures for bone implants. Int J Adv Manuf Technol 100:2915-2927. https://doi.org/10.1007/s00170018-2886-9

41. Yang E, Leary M, Lozanovski B, Downing D, Mazur M, Sarker A, Khorasani AM, Jones A, Maconachie T, Bateman S, Easton M, Qian M, Choong P, Brandt M (2019) Effect of geometry on the mechanical properties of Ti-6Al-4V Gyroid structures fabricated via SLM: a numerical study. Mater Des 184:108165. https://doi. org/10.1016/j.matdes.2019.108165

42. Babamiri BB, Askari H, Hazeli K (2020) Deformation mechanisms and post-yielding behavior of additively manufactured lattice structures. Mater Des 188:108443. https://doi.org/10.1016/j. matdes.2019.108443

43. Aremu A, Maskery I, Tuck C et al. (2014) A comparative finite element study of cubic unit cells for selective laser melting, 25th Solid Freeform Symposium, pp 1238-1249

44. Tan XP, Tan YJ, Chow CSL, Tor SB, Yeong WY (2017) Metallic powder-bed based 3D printing of cellular scaffolds for orthopaedic implants: a state-of-the-art review on manufacturing, topological design, mechanical properties and biocompatibility. Mater Sci Eng C 76:1328-1343. https://doi.org/10.1016/j.msec.2017.02.094

45. Boniotti L, Foletti S, Beretta S, Patriarca L (2020) Analysis of strain and stress concentrations in micro-lattice structures manufactured by SLM. Rapid Prototyp J 26(2):370-380. https:// doi.org/10.1108/RPJ-10-2018-0270

46. Liu S, Shin YC (2019) Additive manufacturing of Ti6Al4V alloy: a review. Mater Des 164:107552. https://doi.org/10.1016/j. matdes.2018.107552

47. Yap CY, Chua CK, Dong ZL et al (2015) Review of selective laser melting: materials and applications. Appl Phys Rev 2. https:// doi.org/10.1063/1.4935926

48. Yakout M, Elbestawi MA, Veldhuis SC (2020) A study of the relationship between thermal expansion and residual stresses in selective laser melting of Ti-6Al-4V. J Manuf Process 52:181-192

49. Wysocki B, Maj P, Krawczy'nska A et al (2017) Microstructure and mechanical properties investigation of $\mathrm{CP}$ titanium processed by selective laser melting (SLM). J Mater Process Technol 241:13-23
50. Lowther M, Louth S, Davey A, Hussain A, Ginestra P, Carter L, Eisenstein N, Grover L, Cox S (2019) Clinical, industrial, and research perspectives on powder bed fusion additively manufactured metal implants. Addit Manuf 28:565-584

51. Liu R, Wang Z, Sparks T et al (2017) Aerospace applications of laser additive manufacturing. Laser Addit Manuf. https://doi.org/ 10.1016/B978-0-08-100433-3.00013-0

52. SLM Solutions (2019) Bugatti develops and builds functional components for high-performance vehicles with the SLM® additive manufacturing technology from SLM Solutions. https://www. slm-solutions.com/it/profilo-aziendale/press-room/press-releases/ bugatti-develops-and-builds-functional-components-for-highperformance-vehicles-with-the-slm-additiv/

53. Ni X, Kong D, Wen Y et al (2019) Anisotropy in mechanical properties and corrosion resistance of $316 \mathrm{~L}$ stainless steel fabricated by selective laser melting. Int J Miner Metall Mater. https:// doi.org/10.1007/s12613-019-1740-x

54. Rosa F, Manzoni S, Casati R (2018) Damping behavior of 316L lattice structures produced by selective laser melting. Mater Des 160:1010-1018. https://doi.org/10.1016/j.matdes.2018.10.035

55. Yakout M, Elbestawi MA, Veldhuis SC (2019) Density and mechanical properties in selective laser melting of Invar 36 and stainless steel 316L. J Mater Process Technol 266:397-420

56. Ripamonti V (2015-2016) Caratterizzazione microstrutturale e frattografica di componenti in acciaio $316 \mathrm{~L}$ prodotti tramite selective laser melting, Bachelor Thesis, Alma Mater Studiorum Università di Bologna, a.a.

57. Harun WSW, Kamariah MSIN, Muhamad N, Ghani SAC, Ahmad F, Mohamed Z (2018) A review of powder additive manufacturing processes for metallic biomaterials. Powder Technol 327:128151. https://doi.org/10.1016/j.powtec.2017.12.058

58. Wang D, Wang Y, Wang J et al (2016) Design and fabrication of a precision template for spine surgery using selective laser melting (SLM). Materials 9:608. https://doi.org/10.3390/ma9070608

59. Allegri G, Colpani A, Ginestra PS et al (2019) An experimental study on micro-milling of a medical grade Co-Cr-Mo alloy produced by selective laser melting. Materials 12

60. Mergulhão MV, Podestá CE, das Neves MDM Mechanical properties and microstructural characterization of cobalt-chromium (CoCr) obtained by casting and selective laser melting (SLM). Mater Sci Forum 899. https://doi.org/10.4028/www.scientific. net/MSF.899.534

61. Ren L, Memarzadeh K, Zhang S, Sun Z, Yang C, Ren G, Allaker RP, Yang K (2016) A novel coping metal material CoCrCu alloy fabricated by selective laser melting with antimicrobial and antibiofilm properties. Mater Sci Eng C 67:461-467. https://doi. org/10.1016/j.msec.2016.05.069

62. Kim HR, Jang S, Kim YK et al (2016) Microstructures and mechanical properties of $\mathrm{Co}-\mathrm{Cr}$ dental alloys fabricated by three $\mathrm{CAD} / \mathrm{CAM}$-based processing techniques. Materials 9:596. https://doi.org/10.3390/ma9070596

63. Averyanova M, Bertrand P, Verquin B (2011) Manufacture of Co-Cr dental crowns and bridges by selective laser melting technology. Virtual Phys Prototyp 6(3):179-185. https://doi.org/10. 1080/17452759.2011.619083

64. León MR, Klemm IM, García-Arranz J et al (2017) 3D metal printing - additive manufacturing technologies for frameworks of implant-borne fixed dental prosthesis. Eur J Prosthodont Restor Dent. https://doi.org/10.1922/EJPRD_RevillaLeon05

65. Aboulkhair NT, Everitt NM, Maskery I et al (2017) Selective laser melting of aluminum alloys. MRS Bull 42. https://doi.org/10. 1557/mrs.2017.63

66. Zhang J, Song B, Wei Q et al (2018) A review of selective laser melting of aluminum alloys: processing, microstructure, property and developing trends. J Mater Sci Technol. https://doi.org/10. 1016/j.jmst.2018.09.004 
67. Gharbi O, Kairy SK, De Lima PR et al (2019) Microstructure and corrosion evolution of additively manufactured aluminium alloy AA7075 as a function of ageing. NPJ Mater Degrad 3:40. https:// doi.org/10.1038/s41529-019-0101-6

68. Yu T, Hyer H, Sohn Y, Bai Y, Wu D (2019) Structure-property relationship in high strength and lightweight AlSi10Mg microlattices fabricated by selective laser melting. Mater Des 182:108062. https://doi.org/10.1016/j.matdes.2019.108062

69. Xiong ZH, Liu SL, Li SF, Shi Y, Yang YF, Misra RDK (2019) Role of melt pool boundary condition in determining the mechanical properties of selective laser melting AlSi10Mg alloy. Mater Sci Eng A 740-741:148-156. https://doi.org/10.1016/j.msea. 2018.10.083

70. SLM Solutions Bugatti produces motor bracket in series. https:// www.slm-solutions.com/en/industries/automotive/bugattiproduces-motor-bracket-in-series/

71. Ho JY, Wong KK, Leong KC, Wong TN (2017) Convective heat transfer performance of airfoil heat sinks fabricated by selective laser melting. Int J Therm Sci 114:213-228. https://doi.org/10. 1016/j.ijthermalsci.2016.12.016

72. Yap CY, Tan HK, Du Z et al (2017) Selective laser melting of nickel powder. Rapid Prototyp J 23(4):750-775. https://doi.org/ 10.1108/RPJ-01-2016-0006

73. R. Muñoz-Moreno, V.D. Divya, S.L. Driver et al., Effect of heat treatment on the microstructure, texture and elastic anisotropy of the nickel-based superalloy CM247LC processed by selective laser melting, Mater Sci Eng A 674(2016)529-539. https://doi.org/ 10.1016/j.msea.2016.06.075

74. Soller S, Barata A, Beyer S et al. Selective laser melting (SLM) of Inconel 718 and stainless steel injectors for liquid rocket engines, SPC2016_312478

75. Caiazzo F, Alfieri V, Corrado G, Argenio P (2017) Laser powder-bed fusion of Inconel 718 to manufacture turbine blades. Int J Adv Manuf Technol 93:4023-4031. https://doi.org/10.1007/s00170-017-0839-3

76. Grosmann A, Gosmann J, Mittelstedt C (2019) Lightweight lattice structures in selective laser melting: design, fabrication and mechanical properties. Mater Sci Eng A 766:138356. https://doi.org/ 10.1016/j.msea.2019.138356

77. Do DK, Li P (2016) The effect of laser energy input on the microstructure, physical and mechanical properties of Ti-6Al-4V alloys by selective laser melting. Virtual Phys Prototyp 11(1):4147. https://doi.org/10.1080/17452759.2016.1142215

78. Zhao X, Li S, Zhang M, Liu Y, Sercombe TB, Wang S, Hao Y, Yang R, Murr LE (2016) Comparison of the microstructures and mechanical properties of $\mathrm{Ti}-6 \mathrm{Al}-4 \mathrm{~V}$ fabricated by selective laser melting and electron beam melting. Mater Des 95:21-31. https:// doi.org/10.1016/j.matdes.2015.12.135

79. Tucho WM, Lysne VH, Austbø $\mathrm{H}$ et al (2018) Investigation of effects of process parameters on microstructure and hardness of SLM manufactured SS316L. J Alloys Compounds. https://doi. org/10.1016/j.jallcom.2018.01.098

80. Dallago M, Raghavendra S, Luchin V et al (2019) Geometric assessment of lattice materials built via selective laser melting. Mater Today: Proc 7:353-361

81. Köhnen P, Haase C, Bültmann J, Ziegler S, Schleifenbaum JH, Bleck W (2018) Mechanical properties and deformation behavior of additively manufactured lattice structures of stainless steel. Mater Des 145:205-217. https://doi.org/10.1016/j.matdes.2018.02.062

82. Choy SY, Sun C, Leong KF et al (2017) Compressive properties of functionally graded lattice structures manufactured by selective laser melting. Mater Des 131:112-120. https://doi.org/10.1016/j. matdes.2017.06.006

83. Choy SY, Sun C, Leong KF et al (2017) Compressive properties of Ti-6 Al-4V lattice structures fabricated by selective laser melting: design, orientation and density. Addit Manuf 16:213-224. https://doi.org/10.1016/j.addma.2017.06.012
84. Leary M, Mazur M, Elambasseril J, McMillan M, Chirent T, Sun Y, Qian M, Easton M, Brandt M (2016) Selective laser melting (SLM) of AlSi12Mg lattice structures. Mater Des 98:344-357. https://doi.org/10.1016/j.matdes.2016.02.127

85. Leary M, Mazur M, Williams H, Yang E, Alghamdi A, Lozanovski B, Zhang X, Shidid D, Farahbod-Sternahl L, Witt G, Kelbassa I, Choong P, Qian M, Brandt M (2018) Inconel 625 lattice structures manufactured by selective laser melting (SLM): mechanical properties, deformation and failure modes. Mater Des 157:179-199. https://doi.org/10.1016/j.matdes.2018.06.010

86. Liverani E, Lutey AHA, Fortunato A et al Characterization of lattice structures for additive manufacturing of lightweight mechanical components, MSEC2017-2835. https://doi.org/10.1115/ MSEC2017-2835

87. Caravaggi P, Liverani E, Leardini A et al (2019) CoCr porous scaffolds manufactured via selective laser melting in orthopedics: topographical, mechanical, and biological characterization. J Biomed Mater Res Part B. https://doi.org/10.1002/jbm.b.34328

88. Xiao Z, Yang Y, Xiao R, Bai Y, Song C, Wang D (2018) Evaluation of topology-optimized lattice structures manufactured via selective laser melting. Mater Des 143:27-37. https://doi.org/ 10.1016/j.matdes.2018.01.023

89. Ataee A, Li Y, Brandt M, Wen C (2018) Ultrahigh-strength titanium gyroid scaffolds manufactured by selective laser melting (SLM) for bone implant applications. Acta Mater 158:354e368354e368. https://doi.org/10.1016/j.actamat.2018.08.005

90. Cutolo A, Engelen B, Desmet W et al (2020) Mechanical properties of diamond lattice $\mathrm{Ti}-6 \mathrm{Al}-4 \mathrm{~V}$ structures produced by laser powder bed fusion: on the effect of the load direction. J Mech Behav Biomed Mater 104:103656. https://doi.org/10.1016/j. jmbbm.2020.103656

91. Campanelli SL, Contuzzi N, Ludovico AD et al (2014) Manufacturing and characterization of Ti6Al4V lattice components manufactured by selective laser melting. Materials 7: 4803-4822. https://doi.org/10.3390/ma7064803

92. Amani Y, Dancette S, Delroisse P, Simar A, Maire E (2018) Compression behavior of lattice structures produced by selective laser melting: X-ray tomography based experimental and finite element approaches. Acta Mater 159:395e407-395e407. https:// doi.org/10.1016/j.actamat.2018.08.030

93. Mager V, Balc N, Leordean D et al (2013) Research on producing complex metal parts with lattice structure, by selective laser melting. Appl Mech Mater 371:280-284. https://doi.org/10.4028/ www.scientific.net/AMM.371.280

94. Ibrahim Y, Li Z, Davies CM, Maharaj C, Dear JP, Hooper PA (2018) Acoustic resonance testing of additive manufactured lattice structures. Addit Manuf 24:566-576. https://doi.org/10.1016/j. addma.2018.10.034

95. Sing SL, Wiria FE, Yeong WY (2018) Selective laser melting of lattice structures: a statistical approach to manufacturability and mechanical behavior. Robot Comput Integr Manuf 49:170-180. https://doi.org/10.1016/j.rcim.2017.06.006

96. Zhong T, He K, Li H, Yang L (2019) Mechanical properties of lightweight $316 \mathrm{~L}$ stainless steel lattice structures fabricated by selective laser melting. Mater Des 181:108076. https://doi.org/ 10.1016/j.matdes.2019.108076

97. Kelly CN, Francovich J, Julmi S, Safranski D, Guldberg RE, Maier HJ, Gall K (2019) Fatigue behavior of As-built selective laser melted titanium scaffolds with sheet-based gyroid microarchitecture for bone tissue engineering. Acta Biomater 94: 610-626. https://doi.org/10.1016/j.actbio.2019.05.046

98. Maskery I, Aboulkhair NT, Aremu AO et al (2016) A mechanical property evaluation of graded density Al-Si10-Mg lattice structures manufactured by selective laser melting. Mater Sci Eng A 670:264-274. https://doi.org/10.1016/j.msea.2016.06.013 
99. Wu M, Chen J, Lin B et al (2017) Improved fatigue endurance ratio of additive manufactured Ti-6Al-4V lattice by hot isostatic pressing. Mater Des 134:163-170. https://doi.org/10.1016/j. matdes.2017.08.048

100. Cutolo A, Neirinck B, Lietaert K, de Formanoir C, van Hooreweder B (2018) Influence of layer thickness and postprocess treatments on the fatigue properties of $\mathrm{CoCr}$ scaffolds produced by laser powder bed fusion. Addit Manuf 23:498504. https://doi.org/10.1016/j.addma.2018.07.008

101. Brenne F, Niendorf T, Maier HJ (2013) Additively manufactured cellular structures: impact of microstructure and local strains on the monotonic and cyclic behavior under uniaxial and bending load. J Mater Process Technol 213:1558-1564. https://doi.org/ 10.1016/j.jmatprotec.2013.03.013

102. Van Hooreweder B, Lietaert K, Neirinck B et al (2017) CoCr F75 scaffolds produced by additive manufacturing: influence of chemical etching on powder removal and mechanical performance. $\mathrm{J}$ Mech Behav Biomed Mater 68:216-223. https://doi.org/10.1016/ j.jmbbm.2017.02.005

103. Van Hooreweder B, Apers Y, Lietaert K et al (2017) Improving the fatigue performance of porous metallic biomaterials produced by selective laser melting. Acta Biomater 47:193-202. https://doi. org/10.1016/j.actbio.2016.10.005

104. Liu F, Zhang DZ, Zhang P et al (2018) Mechanical properties of optimized diamond lattice structure for bone scaffolds fabricated via selective laser melting. Materials 11:374. https://doi.org/10. 3390/ma11030374

105. Limmahakhun S, Oloyede A, Sitthiseripratip K, Xiao Y, Yan C (2017) Stiffness and strength tailoring of cobalt chromium graded cellular structures for stress-shielding reduction. Mater Des 114: 633-641. https://doi.org/10.1016/j.matdes.2016.11.090

106. Bobbert FSL, Lietaert K, Eftekhari AA, Pouran B, Ahmadi SM, Weinans H, Zadpoor AA (2017) Additively manufactured metallic porous biomaterials based on minimal surfaces: a unique combination of topological, mechanical, and mass transport properties. Acta Biomater 53:572-584. https://doi.org/10.1016/j.actbio.2017.02.024

107. Mullen L, Stamp RC, Fox P et al (2009) Selective laser melting: a unit cell approach for the manufacture of porous, titanium, bone in-growth constructs, suitable for orthopedic applications. II. Randomized structures. J Biomed Mater Res B: Appl Biomater. https://doi.org/10.1002/jbm.b.31504

108. Raghavendra S, Molinari A, Fontanari V, Luchin V, Zappini G, Benedetti M, Johansson F, Klarin J (2018) Tensile and compression properties of variously arranged porous Ti-6Al-4V additively manufactured structures via SLM. Procedia Struct Integr 13:149154. https://doi.org/10.1016/j.prostr.2018.12.025

109. Lijun X, Weidong S (2018) Additively-manufactured functionally graded $\mathrm{Ti}-6 \mathrm{Al}-4 \mathrm{~V}$ lattice structures with high strength under static and dynamic loading: experiments. Int J Impact Eng 111:255272. https://doi.org/10.1016/j.ijimpeng.2017.09.018

110. Zhao M, Zhang DZ, Liu F, Li Z, Ma Z, Ren Z (2020) Mechanical and energy absorption characteristics of additively manufactured functionally graded sheet lattice structures with minimal surfaces. Int J Mech Sci 167:105262. https://doi.org/10.1016/j.ijmecsci.2019.105262

111. Al-Saedi DSJ, Masood SH, Faizan-Ur-Rab M et al (2018) Mechanical properties and energy absorption capability of functionally graded F2BCC lattice fabricated by SLM. Mater Des 144: 32-44. https://doi.org/10.1016/j.matdes.2018.01.059

112. Sienkiewicz J, Płatek P, Jiang F, Sun X, Rusinek A (2020) Investigations on the mechanical response of gradient lattice structures manufactured via SLM. Metals 10:213. https://doi.org/10. 3390/met10020213

113. Maconachie T, Leary M, Lozanovski B, Zhang X, Qian M, Faruque O, Brandt M (2019) SLM lattice structures: properties, performance, applications and challenges. Mater Des 183: 108137. https://doi.org/10.1016/j.matdes.2019.108137
114. Kessler J, Bâlc N, Gebhardt A et al (2017) Basic research on lattice structures focused on the reliance of the cross sectional area and additional coatings. MATEC Web of Conferences 94. https://doi. org/10.1051/matecconf/20179403008

115. Hajnyš J, Pagáč M, Zlámal T et al (2018) Stiffness of 316L stainless steel support structures proposed for the SLM process, MATEC Web of Conferences 244. https://doi.org/10.1051/ matecconf $/ 201824401008$

116. Maskery I, Aremu A, Simonelli M et al (2014) The BCC unit cell for latticed SLM parts; mechanical properties as a function of cell size, 25th Solid Free Form Symposium, pp 688-701

117. Löber L, Klemm D, Kühn U, Eckert J (2011) Rapid manufacturing of cellular structures of steel or titanium alumide. Mater Sci Forum 690:103-106. https://doi.org/10.4028/www.scientific.net/ MSF.690.103

118. Kelly CN, Evans NT, Irvin CW, Chapman SC, Gall K, Safranski DL (2019) The effect of surface topography and porosity on the tensile fatigue of 3D printed Ti-6Al-4V fabricated by selective laser melting. Mater Sci Eng C 98:726-736. https://doi.org/10. 1016/j.msec.2019.01.024

119. Barbas A, Bonnet A-S, Lipinski P, Pesci R, Dubois G (2012) Development and mechanical characterization of porous titanium bone substitutes. J Mech Behav Biomed Mater 9:34-44. https:// doi.org/10.1016/j.jmbbm.2012.01.008

120. Raghavendra S, Molinari A, Fontanari V et al (2019) Effect of strut cross section and strut defect on tensile properties of cubic cellular structure. Mat Design Process Comm. https://doi.org/10. 1002/mdp2.118

121. Niu J, Choo HL, Sun W, Mok SH (2018) Numerical study on load-bearing capabilities of beam-like lattice structures with three different unit cells. Int J Mech Mater Des 14:443-460. https://doi. org/10.1007/s10999-017-9384-3(01

122. Kang D, Park S, Son Y, Yeon S, Kim SH, Kim I (2019) Multilattice inner structures for high-strength and light-weight in metal selective laser melting process. Mater Des 175:107786. https://doi. org/10.1016/j.matdes.2019.107786

123. Shen Y, Cantwell W, Li Y (2014) Skin-core adhesion in high performance sandwich structures. J Zhejiang Univ Sci A Appl Phys Eng 15(1):61-67. https://doi.org/10.1631/jzus.A1300283

124. Shen Y, McKown S, Tsopanos S et al (2010) The mechanical properties of sandwich structures based on metal lattice architectures. J Sandwich Struct Mater 12. https://doi.org/10.1177/ 1099636209104536

125. Van Hooreweder B, Kruth J (2017) Advanced fatigue analysis of metal lattice structures produced by selective laser melting. CIRP Ann Manuf Technol 66:221-224. https://doi.org/10.1016/j.cirp. 2017.04.130

126. Contuzzi N, Campanelli SL, Casavola C et al (2013) Manufacturing and characterization of 18Ni Marage 300 lattice components by selective laser melting. Materials 6:3451-3468. https://doi.org/10.3390/ma6083451

127. De Pasquale G, Luceri F, Riccio M (2019) Experimental characterization of SLM and EBM cubic lattice structures for lightweight applications. Exp Mech 59:469-482. https://doi.org/10.1007/ s11340-019-00481-8

128. Feng Q, Tang Q, Liu Y, Setchi R, Soe S, Ma S, Bai L (2017) Quasi-static analysis of mechanical properties of Ti6Al4V lattice structures manufactured using selective laser melting. Int J Adv Manuf Technol 94:2301-2313. https://doi.org/10.1007/s00170017-0932-7

Publisher's note Springer Nature remains neutral with regard to jurisdictional claims in published maps and institutional affiliations. 